WORKING PAPER · NO. 2020-113

\title{
The \$100 Million Nudge: Increasing Tax Compliance of Businesses and the Self-Employed using a Natural Field Experiment
}

Justin E. Holz, John A. List, Alejandro Zentner, Marvin Cardoza, and Joaquin Zentner AUGUST 2020 
The \$100 Million Nudge: Increasing Tax Compliance of Businesses and the Self-Employed using a Natural Field Experiment

Justin E. Holz, John A. List, Alejandro Zentner, Marvin Cardoza, and Joaquin Zentner August 2020

JEL No. C93,H2,H26

\begin{abstract}
$\underline{\text { ABSTRACT }}$
This paper uses a natural field experiment to examine the effectiveness of specific nudges on tax compliance amongst firms and the self-employed in the Dominican Republic. In collaboration with the Dominican Republic's tax authority, we designed messages for more than 28,000 selfemployed workers and over 56,000 firms. Leveraging administrative tax data, we find evidence that our nudges (increasing the salience of prison sentences or public disclosure of tax evaders) have large effects on increasing tax compliance, primarily working through the channel of decreasing claimed tax exemptions. Interestingly, we find that firms are more impacted than the self-employed, and that firm size is critically linked to nudge effectiveness: larger firms are considerably more influenced by nudges than smaller firms. We find this latter result noteworthy given the paucity of evidence showing significant behavioral impacts of nudges amongst the largest players in a market. Overall, our messages increased tax revenue by $\$ 193$ million (roughly $0.23 \%$ of the Dominican Republic's GDP in 2018), with over $\$ 100$ million constituting income that the government would not have received without our field experimental nudges.

Justin E. Holz

Harris School of Public Policy

University of Chicago

Chicago, IL 60637

justinholz@uchicago.edu

John A. List

Department of Economics

University of Chicago

1126 East 59th

Chicago, IL 60637

and NBER

jlist@uchicago.edu

Alejandro Zentner

Naveen Jindal School of Management

University of Texas at Dallas

800 W Campbell Rd.

Richardson, TX 75080

azentner@utdallas.edu

Marvin Cardoza

Direccion General de Impuestos Internos

Av. México \#48

Gascue

Santo Domingo 10204

Dominican Republic

mcardoza@dgii.gov.do

Joaquin Zentner

Inter-American Development Bank

joaquinz@iadb.org
\end{abstract}




\section{Introduction}

Encouraging tax compliance has been central to governments at least since the ancient states of Persia, Greece, Egypt, and Rome began collecting taxes. Over the years, tax collectors as far removed as the Ottomans to the English, have developed clever schemes, such as "tax farming," whereby the government awarded the right to collect taxes to the highest bidder in competitive auctions. For their part, economists have long understood the essential role of financing the provision of public goods for economic growth, especially in developing economies (Smith, 1776; Besley and Ghatak, 2010; Besley and Persson, 2014). Higher tax evasion rates in developing countries generally lead to governments raising substantially lower tax revenue as a share of GDP than higher-income countries (Besley and Persson, 2014). As such, understanding the determinants of tax compliance is a primary objective for governments and policy makers (Slemrod, 2019).

Within economics, tax evasion is understood through the model of (Allingham and Sandmo, 1972), who adapted (Becker, 1968) to the tax compliance context. In this model, taxpayers weigh the financial benefits of evading taxes with the financial penalties they face if their evasion is detected. Experimental studies varying the audit rates or financial penalties generally find effects that align with the model's predictions (Blumenthal et al., 2001; Slemrod et al., 2001; Hasseldine et al., 2007; Kleven et al., 2011; Hallsworth, 2014; Harju et al., 2014; Slemrod, 2016). However, Alm et al. (1992) point out that astronomical levels of risk aversion are necessary to justify the level of compliance observed in most nations and Bérgolo et al. (2017) find evidence consistent with firms exhibiting probability neglect in feared situations.

In response to this criticism, a rich literature on tax morale has attempted to understand non-pecuniary motives for tax compliance (Luttmer and Sing- 
hal, 2014). This literature typically focuses on sending potential tax payers messages that highlight the public goods provided by tax dollars (Bø et al., 2015); increase the salience of tax compliance norms (Hallsworth et al., 2017); change the framing of the message (Hallsworth et al., 2015), or appeal to the morality of the taxpayers (Torgler, 2004). The effect of these messages on tax compliance is inferred from differences in taxes paid between treatment and control groups. Overall, the evidence on the existence of non-pecuniary benefits of tax compliance is mixed while nudges focusing on traditional or social deterrence tend to be more effective (Antinyan and Asatryan, 2019; Slemrod, 2019; Perez-Truglia and Troiano, 2018; Dwenger and Treber, 2018).

Despite the abundance of evidence in favor of using deterrence messages, there are several important gaps in the literature. A key gap involves firm-level compliance. Given that in most countries the tax burden across large and small firms is typically quite disproportionate, a unique feature of our analysis is an exploration of nudge effectiveness across the distribution of firm sizes. In doing so, a natural comparison involves how nudges impact firms versus the selfemployed. To lend empirical insights into these areas, we partner with the internal revenue service in the Dominican Republic (IRSDR hereafter). We sent nearly 84,000 messages to self-employed individuals and firms who collectively paid about $\$ 800$ million in income taxes in FY2018.

In sum, we randomly allocated subjects into one of six groups. Our control group is a simple reminder message sent to taxpayers before the tax deadline. Before our partnership, this was standard practice for the IRSDR. To augment this baseline, we include two deterrence messages. One message increased the salience of potential prison penalties instituted under a new law while the other increased the salience of potential social punishments by emphasizing potential public disclosure of punishments. Then, we interact all 3 of the messages types 
with a reframing of tax mistakes as voluntary choices on the part of the taxpayer (Hallsworth et al., 2015). Using administrative tax data, our key outcome variable is the change in the taxes paid by subjects across the 6 experimental cells.

We report three main results. First, difference-in-differences estimates of the treatment effects suggest that both the threat of public disclosure and prison sentences substantially increase tax compliance. For firms, the public disclosure message increases the amount of taxes paid by an average of $\$ 2,200$ while the prison message increases taxes paid by $\$ 5,300$ (all monetary figures are measured in USD). These effects are primarily driven by declarations: firms that would have declared exempt levels of taxable income are nudged to report positive taxable income. Self-employed workers also increase taxes paid in response to the deterrence messages. However, the measured effects are smaller than for firms: both message types increase tax revenue from self-employed workers by roughly $12 \%$ relative to a simple reminder message. In contrast, the public disclosure and prison messages increase tax revenue from firms by $18 \%$ and $44 \%$, respectively.

Second, the effects of commission framing depend greatly on the perceived underlying punishment and subject pool. When accompanying the control message alone, telling subjects that the IRSDR may view mistakes as an active choice has a negligible effect on tax compliance. Adding the commission message to the public disclosure treatment has a similar negligible effect. However, adding the commission frame to the prison message doubles its magnitude. In this case, firms in our sample increase tax compliance by roughly $100 \%$ while the treatment increases the tax compliance of self-employed workers by $21 \%$. The sensitivity of the commission language treatment effect to the underlying punishment suggests a possible explanation for the disparate findings in (Hallsworth et al., 2015), who find that commission framing doubles taxes paid, and (De Neve 
et al., 2019) who find no effect.

Third, we find that nudge effectiveness is critically related to firm size. While both types of deterrence messages increase the taxes paid from small firms, the nudge effect on large firms is a magnitude higher. Indeed, we find that smaller firms are the least likely to respond to our deterrence messages. This result complements the insightful literature on the tax compliance of small or mediumsized firms ${ }^{1}$ by showing that a key contributor to the tax base (large firms) can be moved by behavioral nudges. This finding has import more generally in that it is rare to experiment on the largest entities in a market, be it a tax, charitable, service, or goods market. In this case, we can observe firms from the entire distribution of sizes. Understanding how large firms react to these types of messages is of great interest to policymakers since the largest firms bear a disproportionate amount of the tax burden (in the DR, $20 \%$ of firms pay over $85+\%$ of corporate income taxes). In this spirit, the finding that the largest firms are those that respond most strongly to nudges from the tax authority represents a new insight in the literature, and opens up the potential for even broader uses of behavioral nudges.

Considering the benefits and costs from this exercise, we find that, overall, treatment messages increased tax compliance by $\$ 193$ million $(0.23 \%$ of the Dominican Republic's GDP in 2018). After accounting for subsequent audits by the IRSDR, we find that more than half of this revenue constitutes income the government would not have received without our treatments. Of course, the marginal costs of our field experiment are trivial since the operational framework was in place when we started and the extra content in the letters represented minimal additional cost

In terms of generalizability of our empirical results, we follow the List (2020)

\footnotetext{
${ }^{1}$ See Pomeranz (2015), Doerrenberg and Schmitz (2015), Bérgolo et al. (2017), and Brockmeyer et al. (2019).
} 
SANS conditions in our reporting. First, in terms of selection, our sample is a subset of the firms and self-employed taxpaying entities in the Dominican Republic. In particular, the IRSDR sent messages to a sample of more than 84,000 self-employed and firms that reported earning more revenue than the average firm in the Dominican Republic in the previous year. In terms of attrition, our compliance rates are $100 \%$, as we have records of the amount of taxes paid for everyone in our sample. Considering naturalness of the choice task, setting, and time frame, we use a natural field experiment (see Harrison and List (2004)), thus our setting is one in which subjects are engaged in a natural task and are not placed on an artificial margin. Finally, in terms of scaling our insights, the results suggest that the benefit cost profile should shrink slightly as the program is extended to the remaining population of the Dominican Republic. This is because we have slightly larger firms in our experiment compared to the overall firm population. Since we view the firm size results as a WAVE1 insight, in the nomenclature of List (2020), replications need to be completed to understand if the size result can be applied to other tax paying populations as well as large players in other markets.

The remainder of our paper proceeds as follows. Section 2 describes the institutional context, subjects, and experimental design. Sections 3 and 4 describe the empirical results. Section 5 concludes.

\section{Background and Experimental Design}

In this section, we describe the institutional context of our experiment, the subject's included in the experiment along with their incentives, and the experimental design. 


\subsection{Institutional Context}

The Dominican Republic is a Caribbean country with GDP per capita of $\$ 8,341$ in 2018, and tax revenue was $13 \%$ of GDP, much lower than the $22.8 \%$ average for all Latin American and Caribbean countries, or the 34.2\% average for all OECD countries. The plurality of tax revenue in the Dominican Republic comes from value-added taxes (35.3\%). The next largest categories are excise taxes $(22.7 \%)$, corporate income taxes (16\%), individual income taxes (9\%), international trade (7.4\%) and property taxes (1.4\%).

Estimated tax evasion in the Dominican Republic was 61.8\% in 2017 (4.22\% of GDP) for the corporate income tax and $57.07 \%$ for the individual income tax (1.68\% of the GDP). This level of tax evasion is higher than other Latin American and Caribbean countries. ${ }^{2}$ To fight high tax evasion, the Dominican Republic's IRS launched an ambitious plan to increase the number of audited taxpayers in 2018. As part of this plan, which involved the matching of taxpayers reported information with third-party information, the audit probability increased from 8\% in 2017 to 12\% in 2018 (Dirección General de Impuestos Internos, 2020).

While prevalent, tax evasion is seen as a socially undesirable activity in the Dominican Republic. The 1995-1999 World Values Survey shows that $68.6 \%$ of the respondents in the Dominican Republic answered that tax evasion is "Never Justifiable," compared to $73 \%$ in the United States, $78.3 \%$ in Uruguay, $71.7 \%$ in Argentina, 52.9\% in Mexico, and 46.5\% in Brazil. More recent information on tax morale is available for Latin American countries from Latinobarómetro. The most recent available wave from year 2016 indicates that $43.6 \%$ of the respondents in the Dominican Republic find tax evasion unjustifiable, compared to $58.1 \%$ in Uruguay, $62.1 \%$ in Argentina, $32.0 \%$ in Mexico, and $49.2 \%$ in Brazil (Lati-

\footnotetext{
${ }^{2}$ Tax evasion for the corporate income tax was $39.6 \%$ in Uruguay, $49.7 \%$ in Argentina, $31.4 \%$ in Mexico, and 26.6\% in Brazil (Gobierno de la República Dominicana: Equipo Interinstitucional, 2018).
} 
nobarómetro Corporation, 2016).

In 2018, The Dominican Republic followed regional efforts to combat money laundering and terrorism financing, enacting a law that severely increased the punishment for tax evasion. Law 155-17 against Money Laundering and Terrorist Financing was approved by the parliament in June 2017, regulated by the presidency in November 2017, and further regulated by the Dominican Republic IRS during 2018. It included tax evasion and other tax-related infractions within a list of offenses penalized with severe criminal punishment including prison and stiff monetary fines. ${ }^{3}$

As this law substantially changes the historically low tax enforcement, the IRS commissioner and high-profile political figures have extensively and fiercely discussed its merits in the media. The media has also discussed cases of taxpayers who have been jailed due to tax evasion and fraud. Recently, for example, 21 taxpayers were sentenced to prison or have spent time in preventive detention awaiting trial, 3 have been placed under house arrest, 7 were ordered to use electronic monitoring devices, and 12 have faced travel restrictions. This list includes business owners, managers, and accountants.

In this paper, we focus on corporate and individual income taxes. In the Dominican Republic, employers are responsible for filing the individual income tax for employees, so we only use individual income taxes paid by self-employed individuals. This portion represents $22.2 \%$ of the total amount collected by the individual income tax. Table 1 shows that the corporate income tax has a flat rate of $27 \%$ and the tax rate on self-employed individuals increases with taxable income reaching $27 \%$ for the top income bracket. Taxable income is computed from subtracting expenses and exempted amounts from gross income. In addition to the low-income tax exemption, there are some special regimes providing

\footnotetext{
${ }^{3}$ Because this law was discussed in the media before the tax deadline in 2018; the law might have affected tax compliance in both 2018 and 2019.
} 
tax exemptions (e.g., individual educational expenses, firms located in free trade zones, social welfare organizations, charities, and sports). Married couples must file the individual income tax separately.

\subsection{Subject Pool}

We conducted our field experiment in collaboration with the IRS of the Dominican Republic (IRSDR). In the months before the experiment, there were 43,973 self-employed workers and 168,497 firms in the agency's database. ${ }^{45}$ From this set, the IRSDR sent messages to 28,180 self-employed workers who collectively paid 100 million USD in taxes in FY2018, along with 56,130 firms who collectively paid nearly 700 million USD in FY2018. We randomly split both the selfemployed and the firms into six different groups to receive different treatment messages (see Table 3$)^{6}$

The subjects in our experiment tend to be larger than those excluded from the experiment. On average, self-employed workers included in the sample pay $54 \%$ more in taxes than those that were not in the experiment while included firms pay $154 \%$ more than excluded firms (see Tables 13 Column (6) and 14 Col-

\footnotetext{
${ }^{4}$ The database only includes self-employed workers who filed taxes in FY2018. All other selfemployed workers are excluded from the experiment and analysis.

${ }^{5}$ Not included in our data are the revenues from some micro-sized firms and self-employed workers who opt to use a simplified tax regime based on an estimated minimum tax instead of based on a percentage of the actual income (https://dgii.gov.do/contribuyentesRegistrados/regimenesEspeciales/RST/Paginas/default.aspx), the revenues from one large firm in a mining sector that uses a special tax form to file taxes (form DPUN-01), and the revenues from income taxes collected on capital gains. There are also some differences between the yearly amounts of tax declared and collected, since the IRSDR collects tax debts from previous years.

${ }^{6}$ Our original intent was to send messages to all 43,973 self-employed workers and 168,497 firms in the IRSDR's sample. However, due to technical issues, the IRSDR sent messages to only the 28,180 self-employed workers and 56,130 firms who we refer to as our experimental sample. Nevertheless, balance was maintained, as treatments in our experimental sample are balanced on observable characteristics (see Tables (9), (10), (11), (12).
} 
umn (5)). This does not affect our ability to measure a treatment effect, but if there is heterogeneity present this will impact how our program will scale, or likewise generalize to the non-included group.

\subsection{Experimental Design}

Each subject's experience follows six steps. First, in FY2018, self-employed individuals and firms decide whether to supply goods and services to the marketplace. Second, at the end of FY2018, the DRIRS sends a message to the subjects with a randomized text. Third, each subject decides whether and when to file their tax return. Fourth, subjects decide how much of their income to report and hence the amount of taxes to pay. Fifth, subjects face the risk of a tax audit by the tax authority. Finally, audited subjects experience the consequences of their decisions while unaudited subjects do not.

As messages were sent shortly before the tax deadline, subjects did not have time to adjust their production decisions before the tax date. Therefore, any changes in the gross-income or losses reported to the DRIRS represent changes in the firms evasion or avoidance decision. In Step 2, the DRIRS sends one of six potential messages to the subject's e-mail address and their "virtual office" that almost all taxpayers use to file taxes. These messages were sent three days before the tax deadline for self-employed workers. Firms received the messages twice, thirty and fifteen days before their tax deadline.

Table 2 summarizes the natural field experimental design. Our control message is a simple reminder about the tax deadline. Thus, our treatment effects are measured relative to a counterfactual in which the DRIRS reminds subjects about the tax date. The reminder message allows us to control for the potential effect of receiving a letter from the tax authority, which past work has shown in and of itself increases tax compliance (Del Carpio, 2013; Perez-Truglia and 
Troiano, 2018; Kettle et al., 2016; Mascagni et al., 2017). Accordingly, our measured treatment effects likely understate the effect of the treatment messages relative to an environment in which the tax authority does not contact subjects before the tax deadline.

The experimental variation induced by our five treatments was the inclusion of short phrases after the reminder message. We constructed the phrases to persuade the recipient to correctly report and pay their tax burden by highlighting either the potential for incarceration or public disclosure of punishments. We also interacted both the control message and deterrence messages with an additional paragraph that informed subjects that the tax authority may interpret misreporting as an active choice.

The public disclosure message reminded subjects about the new law and informed them that any punishments levied for tax evasion will be public record available to the population of the Dominican Republic. This message was constructed to vary the subject's perceived probability of their malfeasance and identify concerns for social punishments. This type of punishment may reduce social image utility (Bénabou and Tirole, 2006; Bursztyn and Jensen, 2017; Butera et al., 2019) or raise concerns about losing customers or employees who prefer to work for civically-minded firms (Hanlon and Slemrod, 2009; Du and Vieira, 2012; McDonnell and King, 2013; Servaes and Tamayo, 2013; List and Momeni, 2017; Hedblom et al., 2019). However, since there is no threat of a formal or centralized list meant to shame tax evaders, this message constitutes a weaker form of shaming than countries commonly practice (Hasegawa et al., 2012; Bø et al., 2015; Hoopes et al., 2018; Dwenger and Treber, 2018) or what has been done with experiments targeting individuals (Perez-Truglia and Troiano, 2018).

The second strategy attempted to use the potential deterrence effects of newly implemented prison sentences for tax evasion. To operationalize these treat- 
ments, we included a phrase reminding subject's of the newly passed law and that prison sentences are now a potential punishment for tax evasion. This message stands in stark contrast with previous papers on tax compliance which investigate the deterrence effects of financial penalties. ${ }^{7}$ Imprisonment, especially of firm owners, is a rare punishment. Given the scarcity of research on the deterrence effects of prison sentences, it is unclear whether this type of deterrence should be viewed as stronger or weaker than traditional deterrence nudges. ${ }^{8}$

We interacted these main messages with a statement that informed subjects that inaccurate information in the tax return may be viewed as an active choice rather than an oversight. These messages are meant to change the behavior of subjects who are evading taxes using an "omission strategy" by increasing the expected punishment for evasion, essentially moving the act of omission to one of commission (Spranca et al., 1991; DeScioli et al., 2011; Hallsworth et al., 2015).

After receiving the messages, subjects proceed to Step 3. Given that we have observed the universe of self-employed workers and firms who choose to file taxes, we have no attrition at this stage of the experiment. However, we can only observe the declarations of firms who file taxes. Therefore, treatment comparisons of gross and net income can only be made for subjects who choose to file their return. On the other hand, we consider firms who chose not to file taxes in FY2019 as paying no taxes in that year.

In Step 4, subjects must determine their tax bill. Table 1 displays the tax brackets for the subjects in our natural field experiment. Firms face a flat tax of $27 \%$ of their taxable income. Self-employed workers, on the other hand, face a

\footnotetext{
${ }^{7}$ See Slemrod (2019) or Antinyan and Asatryan (2019) for reviews of the effect deterrence nudges have on behavior.

${ }^{8}$ Lee and McCrary (2017) note that, unlike fines, prison sentences tend to be dispersed across time. This reduces the deterrence effect of prison sentences relative to fines if individuals heavily discount the future or are hyperbolic discounters. However, since firm decisions are made in groups, rather than individually, they may discount future prison sentences less than individuals would (Charness and Sutter, 2012; Denant-Boemont et al., 2017).
} 
progressive marginal tax system. Workers earning less than $\$ 8,324.40$ in taxable income are exempt from paying income taxes. Those earning between $\$ 8,324.40$ and $\$ 12,468.58$ pay $15 \%$ of their taxable income. Every dollar earned between $\$ 12,468.58$ and $\$ 17,342.46$ is taxed at $20 \%$ and every dollar earned above $\$ 17,342.46$ is taxed at $25 \%$. Both self-employed workers and firms are exempt from paying any taxes if their taxable income is less than or equal to zero.

After making their filing decision, subjects proceed to Step 5, where they face the risk of an audit by the tax authority. Generally, the DRIRS uses two different types of audits. The first is automatic audits that occur when tax entities submit suspicious tax returns. The second type of audit is a full audit where the DRIRS probabilistically chooses some firms to investigate thoroughly. The FY2018 frequency of both types of audits appears in Table 4. Historically, there have been low audit rates for both types of subjects. However, this has increased substantially in the past few years.

Finally, the DRIRS may punish audited subjects based on the audit results. Since the enactment of Law 155-17, more than twenty individuals have been sentenced to prison or spent time in pre-trial detention. About two dozen others have been placed under house arrest, ordered to use electronic monitoring devices or faced travel restrictions. This list includes business owners, managers, and accountants. Because the law substantially affected the historical context of low enforcement tax compliance, it has been discussed in the media. The media has also discussed cases of taxpayers who have been sentenced to prison due to tax evasion. 


\section{Results}

We employ a difference-in-differences model as our main specification. In particular, we estimate models of the following form:

$$
Y_{i, t}=\alpha+\sum_{g \in G} \gamma_{g} \mathbb{1}[G=g]_{i}+\delta_{t} \mathbb{1}[F Y 2019]_{t}+\sum_{g \in G} \beta_{g} \mathbb{1}[G=g, F Y 2019]_{i, t}+\epsilon_{i, t} .
$$

Here, each subject $i$ either receives a reminder message or one treatment message $g \in G=\{$ commission, public, public + commission, prison, prison + commission $\}$. There are two time periods, $\mathcal{T}=\{F Y 2018, F Y 2019\}$. Outcomes observed in FY2018 are measured pre-treatment and outcomes observed in FY2019 are measured post-treatment. The indicator $\mathbb{1}[F Y 2019]_{t}$ is equal to one when the outcomes are after receipt of the treatment messages and the sum $\sum_{g \in G} \gamma_{g} \mathbb{1}[G=g]_{i}$ is a set of indicators representing treatment status. Thus, the interaction of each treatment group with the post variable allows us to estimate the causal parameters, $\beta_{g}$, the intent-to-treat effect of receiving a letter with content $g$ relative to the counterfactual of receiving a reminder letter. ${ }^{9}$

The primary outcome of interest is the amount of taxes paid in FY2019. We also consider several intermediate outcomes to learn more about behavioral changes leading to changes in tax evasion. These intermediate outcomes include: whether the subject chose to file, the amounts of gross revenue and net revenue reported conditional on filing, whether the subject chose to declare an exempt-level of income, and whether the subject received an automatic audit

\footnotetext{
${ }^{9}$ The identifying assumption needed to interpret $\beta_{g}$ as causal effects is that the time trend in outcome $Y_{i t}$ for each treatment group would have been the same as the control group had the DRIRS sent the reminder message to those subjects. This condition is satisfied by randomization of the treatments. Estimates of $\gamma_{g}$ represent pre-treatment differences in $Y_{i, t}$ between group $g$ and the control. These estimates provide evidence on the validity of the identifying assumption. If these values are not statistically different from zero, then the treatments are well-balanced and we can conclude that the randomization was successful.
} 
for their reporting behavior. We cluster standard errors at the individual level, as this was the level at which we assigned treatments.

\subsection{Effect of Treatment Messages on Tax Revenue}

Table 5 presents empirical results of this specification using taxes paid as the outcome variable. Column (1) displays estimates for the pooled self-employed and firm sample, Column (2) displays the estimates for self-employed workers only, and Column (3) displays the estimated treatment effects for the firm subsample. The negative coefficients on the 2019 indicator in both regressions show that, despite the stricter rules against tax evasion, the control group reduced the amount of taxes paid relative to the previous year. This, of course, can be for a variety of reasons that are beyond the scope of this study.

More importantly, overall, both deterrence treatments increase the tax compliance of the subjects. The results in Column (1) show that the public disclosure message increases the amount of taxes paid by $\$ 1,616$ on average relative to the same change in the control group. The effect for prison messages is about double the public disclosure effect. Both the public disclosure and prison time deterrence messages increase the taxes self-employed workers pay by about $\$ 450$, or $13 \%$ of the baseline mean. However, the effect of the public disclosure message is imprecisely estimated for self-employed workers. Firms are much more responsive to deterrence messages. Relative to the baseline mean, the public disclosure message increases taxes paid by firms by $19 \%(\$ 2,190)$ and the prison time message increasing taxes paid by $45 \%(\$ 5,330)$.

In aggregate, the control group paid \$13.37 million less in taxes in FY2019 than they did in FY2018. Relative to this change, the public disclosure treatment increased taxes paid by $\$ 22.81$ million and the prison message increased tax compliance by $\$ 52.17$ million (See Figure 1). This result highlights the im- 
portance of having a control group in FY2019, rather than treating all subjects in FY2019 and using FY2018 as the control (as many tax regulators may desire once they are convinced that the treatment will work).

Potentially at odds with Hallsworth et al. (2015), we find that framing the subject's decision as an active choice did not affect the tax compliance of either selfemployed workers or firms. Intuitively, this discrepancy may result from differences in the perceived probability of detection or the uncertainty of taxes owed. In Hallsworth et al. (2015), for example, the tax agency knew the debt owed by each of the subjects. In contrast, the tax burden is not known in either De Neve et al. (2019) or by the DRIRS in our study. Therefore, subjects may not feel unduly threatened by this message.

Adding the commission message to the public disclosure weakly decreases the effectiveness of the deterrent for both self-employed workers and firms. This is likely the result of counter-veiling forces induced by the treatment. On the one hand, the commission frame increases the perceived harshness of punishments conditional on their realization. Alternatively, punishing those who make errors dilutes the signal peers receive about the subject's type, conditional on punishment. These counter-veiling forces could be working against each other in a way that ends up canceling out their effect.

After accounting for the $\$ 13$ million reduction in taxes from FY2018 to FY2019, adding the commission frame alone decreased total taxes paid by $\$ 4.4$ million. The effect of adding the commission frame message to the public disclosure message had a similar effect, reducing the effectiveness of the public disclosure message by $\$ 3.94$ million. In contrast, the prison + commission message increased taxes paid by $\$ 103.36$ million, $\$ 51.19$ more than the prison message without the commission frame. In total, the experiment increased tax compliance by $\$ 192.79$ million, $0.23 \%$ of the Dominican Republic's gross domestic 
product in 2018.

Next, we estimate the portion of the revenue yield that is new, rather than accelerated. To do this, we use the information on 2019 audits. All of the debt owed by subject's receiving full audits is likely to be recovered by the DRIRS. Therefore, the increase in taxes generated from this group represents accelerated, rather than new revenue. Subjects who receive an automatic audit from the DRIRS will likely have some of their debt recovered. Subjects who are never audited by the DRIRS are unlikely to end up making additional payments to the DRIRS. ${ }^{10}$ Thus, we measure the additional yield generated from treatments as the yield from subjects who are never audited and the accelerated yield generated from treatments as the yield from subjects who receive either type of audit.

Figure 1 shows the total change in revenue for each treatment relative to the control group. Overall $54 \%$ ( $\$ 104.8$ million) of the tax revenue raised by the treatments constitutes new revenue. Up to an additional $\$ 43.02$ million from firms receiving an automatic audit is also new revenue. The $\$ 44.97$ million raised by firms who will receive a full audit represents revenue the Dominican Republic would have received absent treatments. ${ }^{11}$

\subsection{Behavioral Channels at Work}

In order to better understand how subjects choose to evade taxes, we turn our attention to the behavioral changes that resulted in higher tax revenue. In principle, there are several ways in which the treatments could have changed revenue. Table 1 shows the mapping from taxable income to tax burden for firms and the

\footnotetext{
${ }^{10}$ The treatment messages may also change the composition of audited firms. Indeed, we do find that self-employed workers in the commission, public, and prison with commission treatments are less likely to receive automatic audit than those in the control group.

${ }^{11}$ The calculation of new and accelerated revenue relies on the assumption that there will be no future audits that bring in revenue. If new audits occur, the total amount of money raised by the treatments may fall.
} 
self-employed. Higher levels of taxes must come from higher reported levels of taxable income which could be due via changes in the (i) propensity to file, (ii) gross income, (iii) amount of deductions, and propensity to be audited by the DRIRS.

The intent-to-treat effects for each of these outcomes are presented in Table 6 and Table 7. Columns (1) in these tables show that both firms and the selfemployed are less likely to file taxes in 2019 compared to 2018. However, this is to be expected as $100 \%$ of our self-employed worker sample filed in the previous year and some firms exit and those who enter the market are not in the database. None of the treatment messages attenuate this decrease, suggesting that this is not a primary means through which subjects choose to evade taxes. ${ }^{12}$

Column (2) in Table 6 shows that self-employed workers also do not respond to the treatments by changing their reported gross revenue, but instead report higher taxable revenue. Interestingly, Column (4) shows that self-employed workers in the prison with commission frame treatment are less likely to receive an automatic audit. This means that the treatment may create additional cost savings for the IRSDR through a reduction in enforcement costs. Self-employed workers in the commission frame and public disclosure treatments are also less likely to trigger an automatic audit despite not paying additional significantly higher taxes. This is a bit of a puzzle and could imply that firms in these treatments are finding more creative ways to conceal their evasion. Columns (2) and (3) in Table 7 show that firms respond to treatment by increasing both gross revenue and net revenue, reporting nearly $\$ 200,000$ additional gross revenue and $\$ 80,000$ net revenue in our most effective treatment.

While the treatments do not affect the subject's propensity to file taxes they

\footnotetext{
${ }^{12}$ Only self-employed workers who chose to file taxes in FY2018 were included in the experiment. This group may be more or less responsive to deterrence messages than those who did not file previously.
} 
do affect the portion of subjects who report a level of income exempt from taxes. Figure 2 displays the portion of subjects declaring non-exempt levels of income in 2019. Recall that negative net income is exempt for firms while income below $\$ 8,324.40$ is exempt for self-employed individuals. Difference-in-differences estimates of Equation 1 using the propensity to declare an exempt level of taxable income as the outcome measure are presented in Table 8.

Conditional on filing, over $60 \%$ of self-employed workers in the control group and $70 \%$ of firms in the control group declare net income exempt from taxation. Each treatment message reduces the probability that self-employed workers declare exempt income levels with deterrence messages being more effective than the commission frame. Commission frames augment the effect of both the public disclosure message $(p<0.072)$ and the prison message $(p<0.007)$ on the extensive margin for the self-employed.

Despite earning higher gross revenue in FY2019, control group firms are 15 percentage points more likely to declare an exempt level of income in FY2019 relative to FY2018 (See column (3) of Table 8). All treatment messages reduce the probability that firms declare non-positive taxable income. Both types of deterrence messages reduce the portion of firms declaring exempt levels of income by about 20 percentage points. Again, commission frames augment the effect of both the public disclosure message $(p<0.001)$ and the prison message $(p<0.001)$ on the extensive margin. The effects are even larger after conditioning on firms who declared positive earning in FY2019.

\section{Firm Heterogeneity}

A common feature of tax systems is the disproportionate fraction of total revenue paid by the largest firms. For instance, in FY2018, the largest 20 percent of 
firms in the Dominican Republic paid over $85 \%$ of all corporate income taxes. However, previous experimental research on tax compliance has focused on interventions with small and medium sized firms (see, e.g., Ariel (2012), Pomeranz (2015) and Bérgolo et al. (2017)).

It is not obvious whether the largest firms will respond to deterrence nudges in the same way smaller and more well-studied firms have responded. Kleven et al. (2016) argue that tax evasion is more difficult in large firms with accurate business records as the threat of whistleblowing increases with the number of employees. In line with this argument, Kumler et al. (2013) find that tax compliance in Mexico is higher in larger firms. Similarly, Pomeranz (2015) finds that the measured effects of threatening random audits are decreasing in firm size.

Alternatively, if there are high fixed costs to tax evasion, larger firms may evade more, absent treatment, and have greater ability to respond to these interventions. Moreover, Pomeranz (2015) notes that priors about audit probabilities, risk aversion, and other characteristics of the firm may vary with firm size. Importantly, firms in the Dominican Republic primarily operate in the tertiary sector of the economy. Kumler et al. (2013) and Pomeranz (2015) note that firms with a large share of sales going to final consumers will have an easier time evading taxes. Table (16) shows that while a smaller portion of top firms in our sample operate in the tertiary industry, the vast majority of our sample sells directly to customers in every quintile.

To understand the potential heterogeneous effects of nudge treatments across the distribution of firm sizes, we separate firms for whom we observe the number of workers into quintiles. ${ }^{13}$ Then, we estimate the treatment effects on the growth in taxes paid within each of these quintiles. The difference-in-difference

\footnotetext{
${ }^{13}$ We create quintiles using the full sample of data, before sub-setting the data into the experimental sample. The discreteness of the data along with the skewed distribution means that quintiles do not have exactly $20 \%$ of the observations.
} 
values are presented in Figures 4 and 5. Similar patterns emerge for both types of deterrence messages. If we would have conducted the experiment only on small and medium sized firms (those in the bottom $60 \%$ of firm size), then the treatment effects estimated from the experiment would have been economically small and only marginally significant at best. However, we find that the observed effects are much larger for the top two quintiles of firm size.

A key result is that we find that the top $20 \%$ of firms have the largest treatment effect. The average taxes paid by control firms for this quintile fell by $\$ 13,643$. During this same period, taxes paid by the public disclosure group increased by $\$ 9,171$ when used alone and $\$ 3,324$ when combined with the commission treatment. The prison deterrence messages were much more effective also, increasing taxes paid by $\$ 42,299$ when used alone and $\$ 95,846$ when combined with commission. These effects contrast with Pomeranz (2015) and Kumler et al. (2013) who find that tax compliance is lower in smaller firms. This discrepancy may be due to differences in the paper trail associated with the corporate income taxes compared to VATs, or the large portion of firms in our study who sell to final consumers. More work is necessary.

In a general sense, we view our firm size results as potentially novel in the sense that we are unaware of large sample findings showing that the biggest players in a market are affected the deepest by behavioral nudges. While the modal research insights from behavioral and experimental studies are derived from individuals and smaller players in a market, in this sense, our results open up a potential avenue for future research using behavioral interventions on market players that can impact prices and allocations at the most fundamental level. 


\section{Conclusions}

Taxation is one of humankinds oldest and most contentious activities. In modern economies, it continues to play a central role in the development of states (Besley and Persson, 2014). Over the past decade, there has been a surge of literature attempting to increase tax compliance and understand the determinants of evasion. We contribute to this literature by partnering with the Dominican Republic and experimentally evaluating how prison sentences and non-pecuniary motives influence tax compliance (Luttmer and Singhal, 2014). We present the first evidence from a natural field experiment on whether increasing the salience of public disclosure of penalties affects tax compliance behavior in firms. Moreover, in contrast to many earlier experiments on tax compliance, we leverage administrative data to shed insights into how behavioral nudges affect firms across the entire size distribution.

We find that messages highlighting the potential for incarceration for tax evasion are highly effective in increasing tax compliance. Increasing the salience of potential incarceration increases the amount of taxes paid by $45 \%$ for firms and $13 \%$ for self-employed workers. Messages that increase the salience of public disclosure are less effective. These messages do not significantly increase the amount of taxes self-employed workers pay, but increase the amount of taxes firms pay by $19 \%$. The channel for the observed effects is primarily driven by dramatic reductions in the propensity of firm's to declare exempt levels of taxable income.

The effect of commission messaging depends greatly on the perceived punishment regime. The framing effect greatly augmented the prison time message, while weakly backfiring when used with a reminder or when increasing the salience of public disclosure. Overall, the treatments increased the amount of income taxes paid by $\$ 193$ million, with a little over half of this revenue esti- 
mated as "new," rather than accelerated revenue. That is, the government would not have raised this revenue without our treatment messages.

A final insight is that we find that behavioral nudges increase the amount of taxes paid by the largest firms the most. While this result is consistent in our data set, we know less about why this result holds. More specifically, are larger firms responding to reputational concerns from customers, or do larger firms exhibit greater social image concerns than smaller firms? Are there certain institutional facts that cause this asymmetry in treatment effects? We trust that future research will replicate our insights and build theoretical frameworks to enhance our understanding of tax compliance across the firm size dimension. 


\section{Tables}

Table 1: Tax Brackets for Firms and Self-Employed Workers

\begin{tabular}{lll} 
Tax Bracket & Firms & Self-Employed \\
\hline Less than $\$ 0.00$ & Exempt & Exempt \\
$\$ 0.01-\$ 8,324.40$ & $27 \%$ & Exempt \\
$\$ 8,324.40-\$ 12,486.58$ & $27 \%$ & $15 \%$ \\
$\$ 12,486.58-\$ 17,342.46$ & $27 \%$ & $\$ 624.32+20 \%$ of amount above $\$ 12,486.58$ \\
Over $\$ 17,342.46$ & $27 \%$ & $\$ 1,595.52+25 \%$ of amount above $\$ 17,342.46$
\end{tabular}




\section{Table 2: Treatment Messages}

\begin{tabular}{|c|c|c|}
\hline & Without Commission Frame & With Commission Frame \\
\hline Control & $\begin{array}{l}\text { We remind you that the deadline of the obli- } \\
\text { gation of filing and paying the income tax } \\
\text { return for year } 2018 \text { is on [TAX DATE]. }\end{array}$ & $\begin{array}{l}\text { We remind you that the deadline of the obli- } \\
\text { gation of filing and paying the income tax } \\
\text { return for year } 2018 \text { is on [TAX DATE]. } \\
\text { Bear in mind that providing inaccurate infor- } \\
\text { mation in the tax return might not be con- } \\
\text { sidered as an oversight, but as a voluntary } \\
\text { choice, which would represent a violation of } \\
\text { your obligations as a taxpayer as established } \\
\text { in articles } 253 \text { and } 254 \text { of the tax code. }\end{array}$ \\
\hline Public & $\begin{array}{l}\text { We remind you that the deadline of the obli- } \\
\text { gation of filing and paying the income tax } \\
\text { return for year } 2018 \text { is on [TAX DATE]. } \\
\text { Bear in mind that providing inaccurate infor- } \\
\text { mation in the tax return could be considered } \\
\text { a violation of the provisions of the new law } \\
155-17 \text { against money laundering and terror- } \\
\text { ism financing, and that the specifics of the } \\
\text { imposed punishment would be public infor- } \\
\text { mation available to the whole the population } \\
\text { once the ruling is final. }\end{array}$ & $\begin{array}{l}\text { We remind you that the deadline of the obli- } \\
\text { gation of filing and paying the income tax } \\
\text { return for year } 2018 \text { is on [TAX DATE]. } \\
\text { Bear in mind that providing inaccurate infor- } \\
\text { mation in the tax return might not be con- } \\
\text { sidered as an oversight, but as a voluntary } \\
\text { choice, which would represent a violation of } \\
\text { your obligations as a taxpayer as established } \\
\text { in articles } 253 \text { and } 254 \text { of the tax code. } \\
\text { In addition, providing inaccurate information } \\
\text { in the tax return could be considered a vio- } \\
\text { lation of the provisions of the new law 155- } \\
17 \text { against money laundering and terrorism } \\
\text { financing, and that the specifics of the im- } \\
\text { posed punishment would be public informa- } \\
\text { tion available to the whole the population } \\
\text { once the ruling is final. }\end{array}$ \\
\hline Prison & $\begin{array}{l}\text { We remind you that the deadline of the obli- } \\
\text { gation of filing and paying the income tax } \\
\text { return for year } 2018 \text { is on [TAX DATE]. } \\
\text { Bear in mind that as established by the new } \\
\text { law } 155-17 \text { against money laundering and } \\
\text { terrorism financing, providing inaccurate in- } \\
\text { formation in the tax return could be punished } \\
\text { with prison. }\end{array}$ & $\begin{array}{l}\text { We remind you that the deadline of the obli- } \\
\text { gation of filing and paying the income tax } \\
\text { return for year } 2018 \text { is on [TAX DATE]. } \\
\text { Bear in mind that providing inaccurate infor- } \\
\text { mation in the tax return might not be con- } \\
\text { sidered as an oversight, but as a voluntary } \\
\text { choice, which would represent a violation of } \\
\text { your obligations as a taxpayer as established } \\
\text { in articles } 253 \text { and } 254 \text { of the tax code. } \\
\text { In addition, as established by the new law } \\
155-17 \text { against money laundering and terror- } \\
\text { ism financing, providing inaccurate informa- } \\
\text { tion in the tax return could be punished with } \\
\text { prison. }\end{array}$ \\
\hline
\end{tabular}

Note: The messages used in the experiment were written in Spanish. Translated messages appear in the table. 
Table 3: Sample Sizes

\begin{tabular}{|c|c|c|c|}
\hline \multirow{8}{*}{ 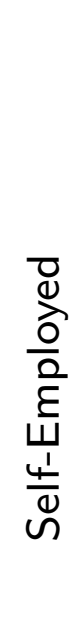 } & & Population & Sent Message \\
\hline & Total & 43,973 & 28,180 \\
\hline & Control & 7,328 & 4,723 \\
\hline & Commission & 7,329 & 4,781 \\
\hline & Jail time & 7,329 & 4,728 \\
\hline & Public Disclosure & 7,329 & 4,736 \\
\hline & Commission and Jail Time & 7,329 & 4,518 \\
\hline & Commission and Disclosure & 7,329 & 4,694 \\
\hline \multirow{7}{*}{$\sum_{i=}^{n}$} & Total & 168,497 & 56,310 \\
\hline & Control & 28,082 & 9,386 \\
\hline & Commission & 28,084 & 9,393 \\
\hline & Jail time & 28,083 & 9,381 \\
\hline & Public Disclosure & 28,083 & 9,388 \\
\hline & Commission and Jail Time & 28,083 & 9,389 \\
\hline & Commission and Disclosure & 28,082 & 9,373 \\
\hline
\end{tabular}




\section{Table 4: Audit Rates for Firms and Self-Employed Workers}

\begin{tabular}{lcccc} 
& 2018 Either Audit & 2018 Automatic Audit & 2018 Full Audit & 2018 Both Audits \\
\hline Self-Employed & $2360(8.38 \%)$ & $2334(8.28 \%)$ & $29(0.10 \%)$ & $3(0.01 \%)$ \\
Firms & $3781(6.71 \%)$ & $3635(6.46 \%)$ & $182(0.32 \%)$ & $36(0.06 \%)$ \\
& & & \\
Combined & $6141(7.27 \%)$ & $5969(7.06 \%)$ & $211(0.25 \%)$ & $39(0.05 \%)$ \\
\hline \hline
\end{tabular}

Note: Table displays the number of audits by type and tax-paying entity for all subjects in the experimental sample. These audits occurred before the experiment in FY2018. 


\section{Table 5: Average Effects of Treatment Messages on Change in Taxes Paid}

\begin{tabular}{|c|c|c|c|}
\hline & $\begin{array}{c}(1) \\
\text { Taxes Paid }\end{array}$ & $\begin{array}{c}(2) \\
\text { Taxes Paid }\end{array}$ & $\begin{array}{c}(3) \\
\text { Taxes Paid }\end{array}$ \\
\hline \multirow[t]{2}{*}{ Commission Framing } & -307.9 & 250.8 & -595.8 \\
\hline & $(828.5)$ & $(319.8)$ & $(1237.9)$ \\
\hline \multirow[t]{2}{*}{ Public Disclosure } & $1616.1^{* *}$ & 477.0 & $2190.0^{* *}$ \\
\hline & $(783.7)$ & $(844.3)$ & $(1099.0)$ \\
\hline \multirow[t]{2}{*}{ Public Disclosure with Commission Framing } & 1338.4 & -134.0 & 2077.3 \\
\hline & $(1494.1)$ & $(355.6)$ & $(2235.6)$ \\
\hline \multirow[t]{2}{*}{ Prison Time } & $3697.7^{* *}$ & $457.6^{* *}$ & $5330.2^{* *}$ \\
\hline & $(1490.0)$ & $(198.1)$ & $(2238.5)$ \\
\hline \multirow[t]{2}{*}{ Prison Time with Commission Framing } & $7419.1^{* * *}$ & $740.4^{* * *}$ & $10645.5^{* * *}$ \\
\hline & $(1602.2)$ & $(255.7)$ & $(2372.5)$ \\
\hline \multirow[t]{2}{*}{2019 indicator } & $-947.8^{*}$ & $-347.7^{* *}$ & $-1249.8^{*}$ \\
\hline & $(493.4)$ & $(166.0)$ & $(736.9)$ \\
\hline \multirow[t]{2}{*}{ Pre-treatment: Commission Framing } & 174.5 & 85.17 & 214.5 \\
\hline & $(2545.6)$ & $(392.9)$ & $(3828.1)$ \\
\hline \multirow[t]{2}{*}{ Pre-treatment: Public Disclosure } & 246.0 & 87.31 & 324.9 \\
\hline & $(2505.4)$ & $(588.6)$ & $(3755.9)$ \\
\hline \multirow[t]{2}{*}{ Pre-treatment: Public Disclosure with Commission Framing } & -23.89 & 42.90 & -55.05 \\
\hline & $(3151.1)$ & $(478.9)$ & $(4726.1)$ \\
\hline \multirow[t]{2}{*}{ Pre-treatment: Prison Time } & 1466.3 & -268.7 & 2339.9 \\
\hline & $(3999.1)$ & $(366.5)$ & $(6010.9)$ \\
\hline \multirow[t]{2}{*}{ Pre-treatment: Prison Time with Commission Framing } & 9.437 & 295.6 & -107.1 \\
\hline & $(3001.5)$ & $(385.0)$ & $(4472.4)$ \\
\hline \multirow[t]{2}{*}{ Constant } & 2607.3 & $3561.3^{* * *}$ & $11824.7^{* * *}$ \\
\hline & $(1875.6)$ & $(279.9)$ & $(2932.9)$ \\
\hline Subjects & Self-Employed and Firms & Self-Employed & Firms \\
\hline Subject Indicator & YES & NO & NO \\
\hline Baseline balance & .997 & .618 & .996 \\
\hline Observations & 168978 & 56358 & 112620 \\
\hline
\end{tabular}




\section{Table 6: Treatment Effects on the Filing Behavior of Self-Employed Workers}

\begin{tabular}{|c|c|c|c|c|c|}
\hline & $\begin{array}{l}\quad(1) \\
\text { Filed Taxes }\end{array}$ & $\begin{array}{c}(2) \\
\text { Gross Revenue }\end{array}$ & $\begin{array}{c}(3) \\
\text { Taxable Revenue }\end{array}$ & $\begin{array}{c}\text { (4) } \\
\text { Auto Audit }\end{array}$ & $\begin{array}{l}\text { (5) } \\
\text { Full Audit }\end{array}$ \\
\hline \multirow[t]{2}{*}{ Commission Framing } & 0.00264 & 4071.6 & 1461.6 & $-0.0130 * *$ & $0.00104^{*}$ \\
\hline & $(0.00819)$ & $(5531.9)$ & $(1672.0)$ & $(0.00520)$ & $(0.000629)$ \\
\hline \multirow[t]{2}{*}{ Public Disclosure } & -0.00600 & -409.5 & 2815.7 & $-0.0137^{* * *}$ & -0.00000116 \\
\hline & $(0.00827)$ & $(6414.7)$ & $(3990.5)$ & $(0.00520)$ & $(0.000423)$ \\
\hline \multirow[t]{2}{*}{ Public Disclosure with Commission Framing } & 0.000468 & -4074.1 & -365.7 & -0.00763 & 0.000429 \\
\hline & $(0.00824)$ & $(5511.9)$ & $(1578.1)$ & $(0.00532)$ & $(0.000521)$ \\
\hline \multirow[t]{2}{*}{ Prison Time } & -0.00127 & -360.3 & $2352.6^{* *}$ & -0.00812 & -0.000000448 \\
\hline & $(0.00824)$ & $(4879.8)$ & $(1071.7)$ & $(0.00530)$ & $(0.000423)$ \\
\hline \multirow[t]{2}{*}{ Prison Time with Commission Framing } & 0.000616 & 7344.6 & $4334.6^{* * *}$ & $-0.0127^{* *}$ & 0.000241 \\
\hline & $(0.00832)$ & $(4724.9)$ & $(1314.2)$ & $(0.00528)$ & $(0.000486)$ \\
\hline \multirow[t]{2}{*}{2019 indicator } & $-0.200 * * *$ & $10996.8^{* * *}$ & $1715.8^{*}$ & $0.0756^{* * *}$ & 0.000423 \\
\hline & $(0.00582)$ & $(3482.4)$ & $(894.9)$ & $(0.00385)$ & $(0.000299)$ \\
\hline \multirow{2}{*}{ Pre-treatment: Commission Framing } & $-8.35 e-15$ & 3541.3 & 307.6 & -0.00669 & -0.000434 \\
\hline & $(1.32 \mathrm{e}-09)$ & $(7409.8)$ & $(1578.0)$ & $(0.00565)$ & $(0.000666)$ \\
\hline \multirow[t]{2}{*}{ Pre-treatment: Public Disclosure } & $-1.37 e-14$ & -5956.3 & 323.7 & -0.00889 & -0.000426 \\
\hline & $(1.47 \mathrm{e}-09)$ & $(6623.5)$ & $(2358.6)$ & $(0.00563)$ & $(0.000669)$ \\
\hline \multirow[t]{2}{*}{ Pre-treatment: Public Disclosure with Commission } & $-2.03 e-14$ & -7322.9 & 126.2 & -0.00458 & -0.000631 \\
\hline & $()$. & $(7764.7)$ & $(1920.7)$ & $(0.00571)$ & $(0.000636)$ \\
\hline \multirow[t]{2}{*}{ Pre-treatment: Prison Time } & $-1.28 \mathrm{e}-14$ & -1315.9 & -1095.3 & 0.00202 & 0.000422 \\
\hline & $(1.28 \mathrm{e}-09)$ & $(6894.2)$ & $(1472.8)$ & $(0.00580)$ & $(0.000791)$ \\
\hline \multirow[t]{2}{*}{ Pre-treatment: Prison Time with Commission Framing } & $-3.65 e-15$ & 8114.3 & 1149.5 & -0.000507 & -0.000385 \\
\hline & $(1.63 \mathrm{e}-09)$ & $(9173.1)$ & $(1547.7)$ & $(0.00583)$ & $(0.000682)$ \\
\hline \multirow[t]{2}{*}{ Constant } & $1.000^{* * *}$ & $76550.7^{* * *}$ & $16210.6^{* * *}$ & $0.0860^{* * *}$ & $0.00127^{* *}$ \\
\hline & $(1.31 \mathrm{e}-09)$ & $(4742.0)$ & $(1124.3)$ & $(0.00408)$ & $(0.000518)$ \\
\hline Subjects & Firms & Firms & Firms & Firms & Firms \\
\hline Baseline balance & 1 & .393 & .628 & .295 & .683 \\
\hline R-squared & 0.112 & 0.000 & 0.000 & 0.011 & 0.000 \\
\hline Observations & 56358 & 50703 & 50703 & 56358 & 56358 \\
\hline
\end{tabular}




\section{Table 7: Treatment Effects on the Filing Behavior of Firms}

\begin{tabular}{|c|c|c|c|c|c|}
\hline & $\begin{array}{l}(1) \\
\text { Filed Taxes }\end{array}$ & $\begin{array}{c}(2) \\
\text { Gross Revenue }\end{array}$ & $\begin{array}{c}\text { (3) } \\
\text { Taxable Revenue }\end{array}$ & $\begin{array}{c}\text { (4) } \\
\text { Auto Audit }\end{array}$ & $\begin{array}{l}\text { (5) } \\
\text { Full Audit }\end{array}$ \\
\hline \multirow[t]{2}{*}{ Commission Framing } & 0.00408 & 89242.3 & 20143.3 & 0.00294 & 0.000425 \\
\hline & $(0.00599)$ & $(56796.3)$ & $(20936.0)$ & $(0.00321)$ & $(0.000499)$ \\
\hline \multirow[t]{2}{*}{ Public Disclosure } & -0.00372 & $132171.9^{* *}$ & $53400.1^{* * *}$ & -0.00150 & 0.000639 \\
\hline & $(0.00599)$ & $(65091.9)$ & $(20012.7)$ & $(0.00315)$ & $(0.000522)$ \\
\hline \multirow[t]{2}{*}{ Public Disclosure with Commission Framing } & -0.00582 & -17329.5 & $69188.4^{* *}$ & -0.000252 & 0.000215 \\
\hline & $(0.00606)$ & $(131766.4)$ & $(29424.9)$ & $(0.00316)$ & $(0.000477)$ \\
\hline \multirow[t]{2}{*}{ Prison Time } & -0.00429 & $126699.0^{*}$ & $73968.8^{* * *}$ & -0.0000803 & 0.000747 \\
\hline & $(0.00602)$ & $(74173.6)$ & $(26296.9)$ & $(0.00317)$ & $(0.000533)$ \\
\hline \multirow[t]{2}{*}{ Prison Time with Commission Framing } & -0.000413 & $188287.0^{* *}$ & $110880.0^{* * *}$ & 0.00254 & 0.000532 \\
\hline & $(0.00599)$ & $(84001.5)$ & $(25786.8)$ & $(0.00321)$ & $(0.000511)$ \\
\hline \multirow[t]{2}{*}{2019 indicator } & $-0.0413^{* * *}$ & $147672.2^{* * *}$ & $-34415.4^{*}$ & $0.0493^{* * *}$ & $0.000959^{* * *}$ \\
\hline & $(0.00425)$ & $(33467.2)$ & $(18340.7)$ & $(0.00224)$ & $(0.000319)$ \\
\hline \multirow[t]{2}{*}{ Pre-treatment: Commission Framing } & 0.000337 & 127211.4 & 5676.9 & $-0.00612^{*}$ & 0.000530 \\
\hline & $(0.00726)$ & $(259344.5)$ & $(29168.2)$ & $(0.00354)$ & $(0.000844)$ \\
\hline \multirow[t]{2}{*}{ Pre-treatment: Public Disclosure } & 0.000203 & 30489.4 & 8701.3 & -0.00459 & -0.000107 \\
\hline & $(0.00726)$ & $(249372.1)$ & $(28817.7)$ & $(0.00356)$ & $(0.000803)$ \\
\hline \multirow[t]{2}{*}{ Pre-treatment: Public Disclosure with Commission } & -0.000840 & 259399.9 & -11900.5 & 0.000411 & 0.000751 \\
\hline & $(0.00727)$ & $(379508.5)$ & $(38984.4)$ & $(0.00363)$ & $(0.000858)$ \\
\hline \multirow[t]{2}{*}{ Pre-treatment: Prison Time } & -0.000241 & 168222.9 & 25935.6 & 0.000994 & -0.000105 \\
\hline & $(0.00727)$ & $(367519.2)$ & $(42529.6)$ & $(0.00363)$ & $(0.000803)$ \\
\hline \multirow[t]{2}{*}{ Pre-treatment: Prison Time with Commission Framing } & 0.000357 & 13688.6 & 11041.0 & 0.00158 & -0.000214 \\
\hline & $(0.00726)$ & $(263630.9)$ & $(32688.0)$ & $(0.00364)$ & $(0.000796)$ \\
\hline \multirow[t]{2}{*}{ Constant } & $0.548^{* * *}$ & $1122403.6^{* * *}$ & $55424.5^{* *}$ & $0.0658 * * *$ & $0.00309^{* * *}$ \\
\hline & $(0.00514)$ & $(185849.4)$ & $(23379.7)$ & $(0.00256)$ & $(0.000573)$ \\
\hline Subjects & Firms & Firms & Firms & Firms & Firms \\
\hline Baseline balance & 1 & .957 & .952 & .092 & .717 \\
\hline R-squared & 0.002 & 0.000 & 0.000 & 0.008 & 0.000 \\
\hline Observations & 112620 & 59331 & 59331 & 112620 & 112620 \\
\hline
\end{tabular}


Table 8: Propensity to Declare Exempt Income Level

\begin{tabular}{|c|c|c|c|c|}
\hline & $\begin{array}{c}(1) \\
\text { Exempt Net-Income Level }\end{array}$ & $\begin{array}{c}\text { (2) } \\
\text { Exempt Net-Income Level }\end{array}$ & $\begin{array}{c}\text { (3) } \\
\text { Exempt Net-Income Level }\end{array}$ & $\begin{array}{c}\text { (4) } \\
\text { Exempt Net-Income Level }\end{array}$ \\
\hline \multirow[t]{2}{*}{ Commission } & $-0.0189^{* *}$ & $-0.0191^{* *}$ & $-0.0371^{* * *}$ & $-0.0549^{* * * *}$ \\
\hline & $(0.00931)$ & $(0.00943)$ & $(0.0106)$ & $(0.0140)$ \\
\hline \multirow[t]{2}{*}{ Public } & $-0.0360^{* * *}$ & $-0.0371^{* * *}$ & $-0.180^{* * *}$ & $-0.260^{* * *}$ \\
\hline & $(0.00954)$ & $(0.00968)$ & $(0.0103)$ & $(0.0134)$ \\
\hline \multirow[t]{2}{*}{ Public \& Commission Frame } & $-0.0415^{* * *}$ & $-0.0428 * * *$ & $-0.213^{* * *}$ & $-0.302^{* * *}$ \\
\hline & $(0.00966)$ & $(0.00978)$ & $(0.0103)$ & $(0.0134)$ \\
\hline \multirow[t]{2}{*}{ Prison } & $-0.0479^{* * *}$ & $-0.0488^{* * *}$ & $-0.185^{* * *}$ & $-0.272^{* * *}$ \\
\hline & $(0.00973)$ & $(0.00985)$ & $(0.0103)$ & $(0.0135)$ \\
\hline \multirow[t]{2}{*}{ Prison \& Commission Frame } & $-0.0664^{* * *}$ & $-0.0679^{* * *}$ & $-0.234^{* * *}$ & $-0.341^{* * *}$ \\
\hline & $(0.00970)$ & $(0.00983)$ & $(0.0103)$ & $(0.0134)$ \\
\hline \multirow[t]{2}{*}{2019 indicator } & 0.00176 & -0.00887 & $0.153^{* * *}$ & $0.255^{* * *}$ \\
\hline & $(0.00656)$ & $(0.00666)$ & $(0.00761)$ & $(0.00996)$ \\
\hline \multirow[t]{2}{*}{ FY2018: Commission Framing } & 0.00332 & 0.00386 & 0.00449 & 0.000910 \\
\hline & $(0.00984)$ & $(0.00984)$ & $(0.00979)$ & $(0.0114)$ \\
\hline \multirow[t]{2}{*}{ FY2018: Public } & 0.00606 & 0.00613 & -0.00110 & -0.00907 \\
\hline & $(0.00985)$ & $(0.00986)$ & $(0.00980)$ & $(0.0114)$ \\
\hline \multirow[t]{2}{*}{ FY2018: Public \& Commission Frame } & 0.00651 & 0.00725 & 0.00610 & -0.00410 \\
\hline & $(0.00987)$ & $(0.00988)$ & $(0.00980)$ & $(0.0114)$ \\
\hline \multirow[t]{2}{*}{ FY2018: Prison } & 0.000592 & 0.000745 & 0.00287 & 0.00185 \\
\hline & $(0.00988)$ & $(0.00988)$ & $(0.00980)$ & $(0.0114)$ \\
\hline \multirow[t]{2}{*}{ FY2018: Prison \& Commission Frame } & 0.00195 & 0.00228 & 0.00509 & 0.00720 \\
\hline & $(0.00999)$ & $(0.00999)$ & $(0.00979)$ & $(0.0114)$ \\
\hline \multirow[t]{2}{*}{ Constant } & $0.640^{* * *}$ & $0.640^{* * *}$ & $0.554^{* * *}$ & $0.339^{* * *}$ \\
\hline & $(0.00699)$ & $(0.00699)$ & $(0.00693)$ & $(0.00804)$ \\
\hline Subjects & Self-Employed & Self-Employed & Firms & Firms \\
\hline Gross Income Declared & Any & Positive & Any & Positive \\
\hline Baseline balance & 0.970 & 0.965 & 0.956 & 0.67 \\
\hline Observations & 50703 & 50035 & 59331 & 40623 \\
\hline
\end{tabular}




\section{Figures}

Figure 1: Total Revenue Growth Raised by Treatments

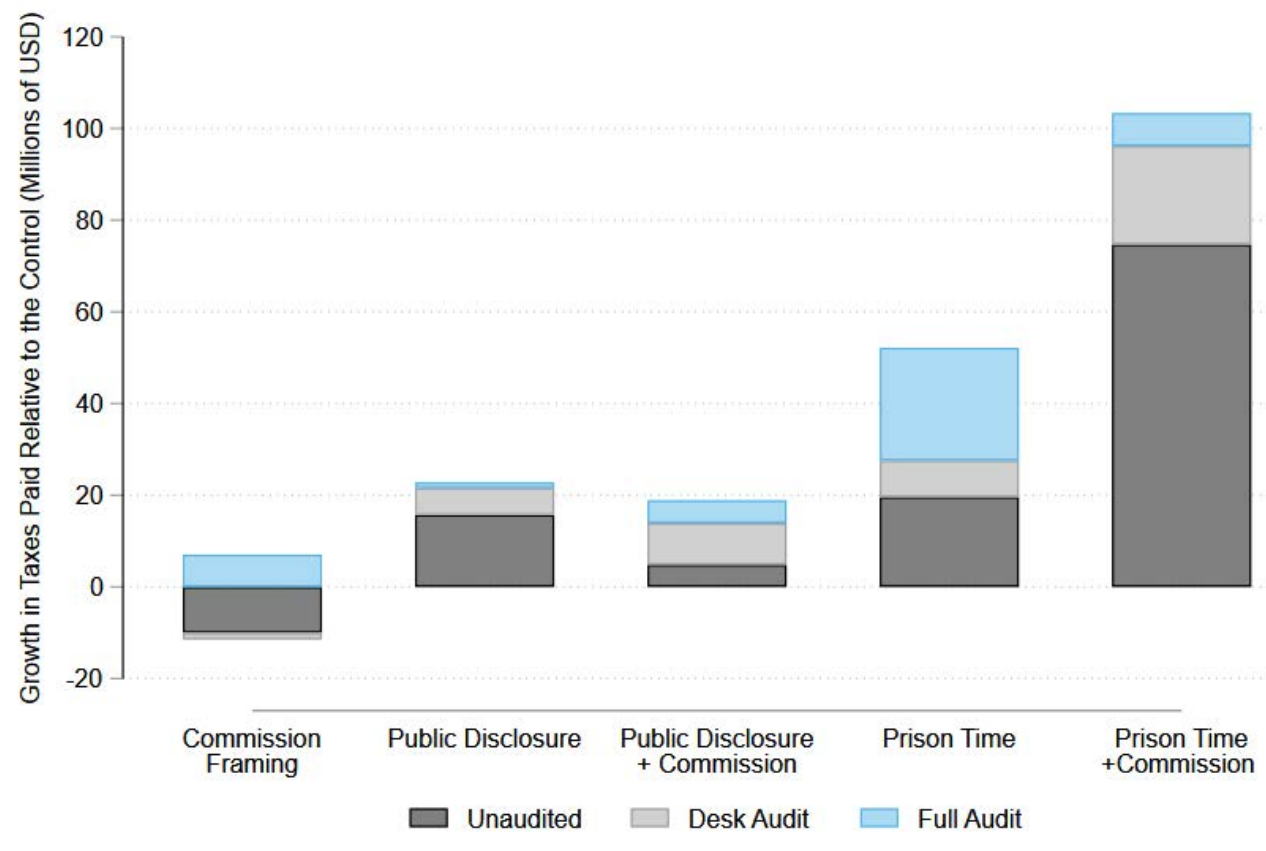

Note: Figure displays the difference between the total tax revenue growth in each treatment less the tax revenue growth in the control group, pooling selfemployed workers and firms. Values are calculated separately for each of the three subgroups. These groups are (i) subjects who are never audited, (ii) subjects who received an automatic desk audit, and (iii) subjects who received a full audit. Revenue in the control group fell by $\$ 13.37$ million to $\$ 114.43$ million in 2019 . Additional $\$ 192.79$ million raised by treatments. 
Figure 2: Portion of Self-Employed Declaring Exempt Income 2019

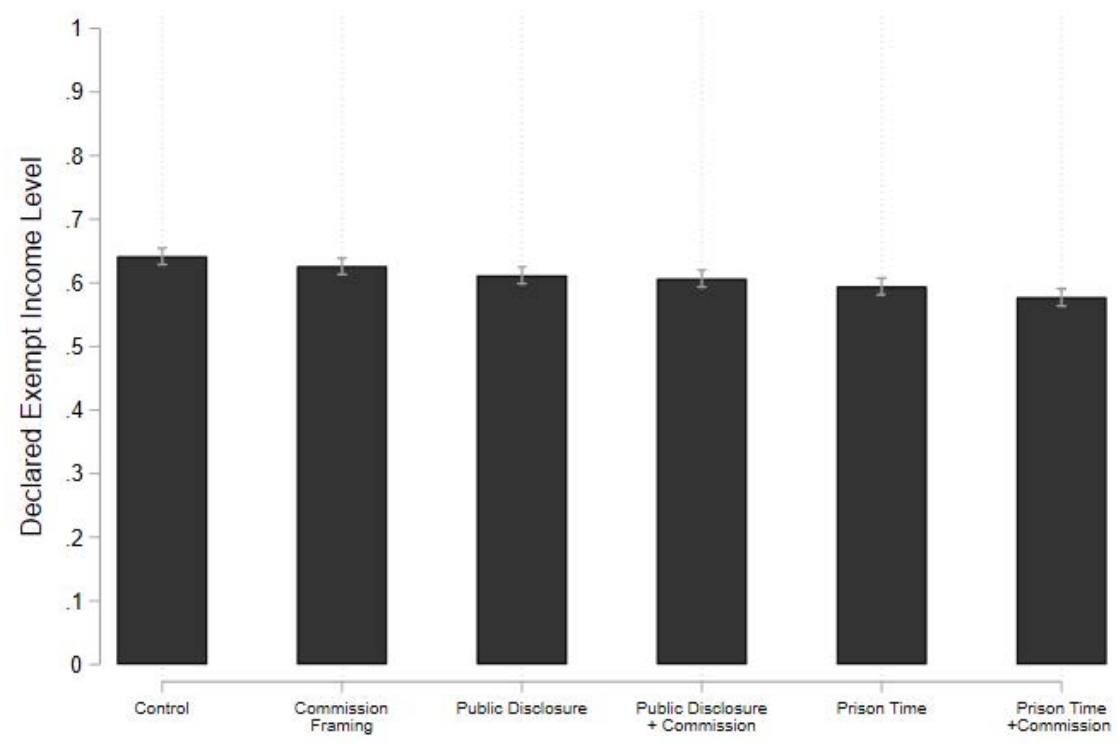

Figure 3: Portion of Firms Declaring Exempt Income 2019

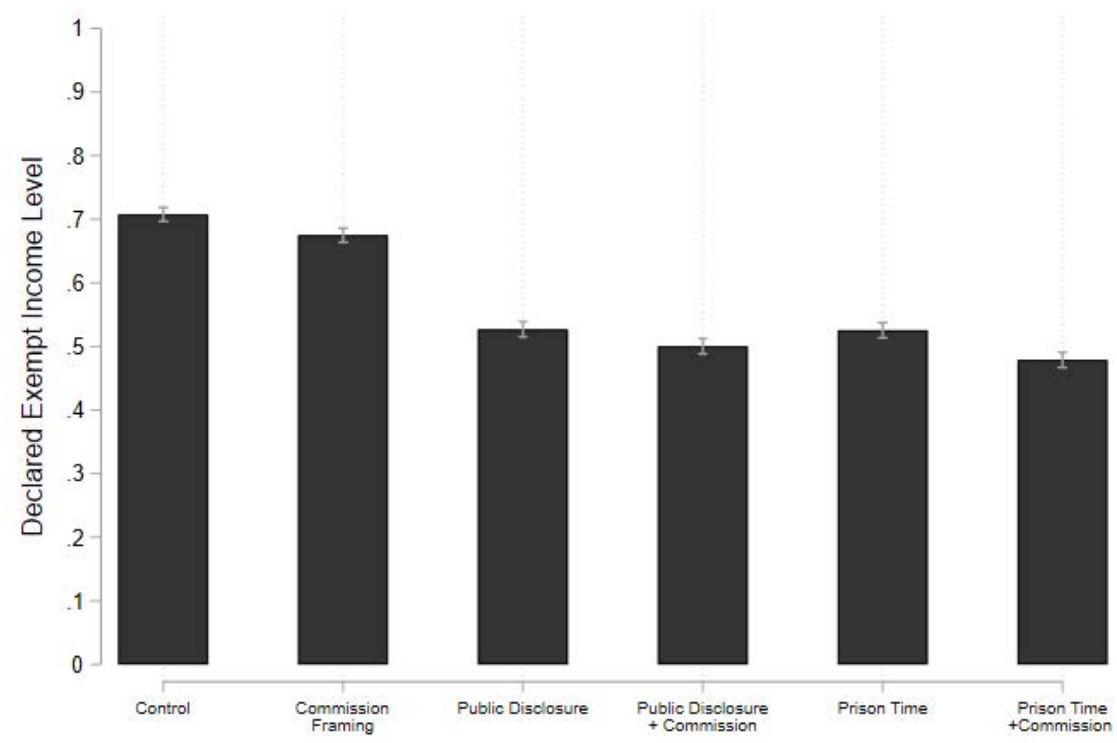

Note: Figures displays the portion of firms and self-employed workers declaring positive taxable income in 2019 by treatment along with $90 \%$ Confidence intervals. 


\section{Figure 4: Effect of Prison Messages by Firm Size}

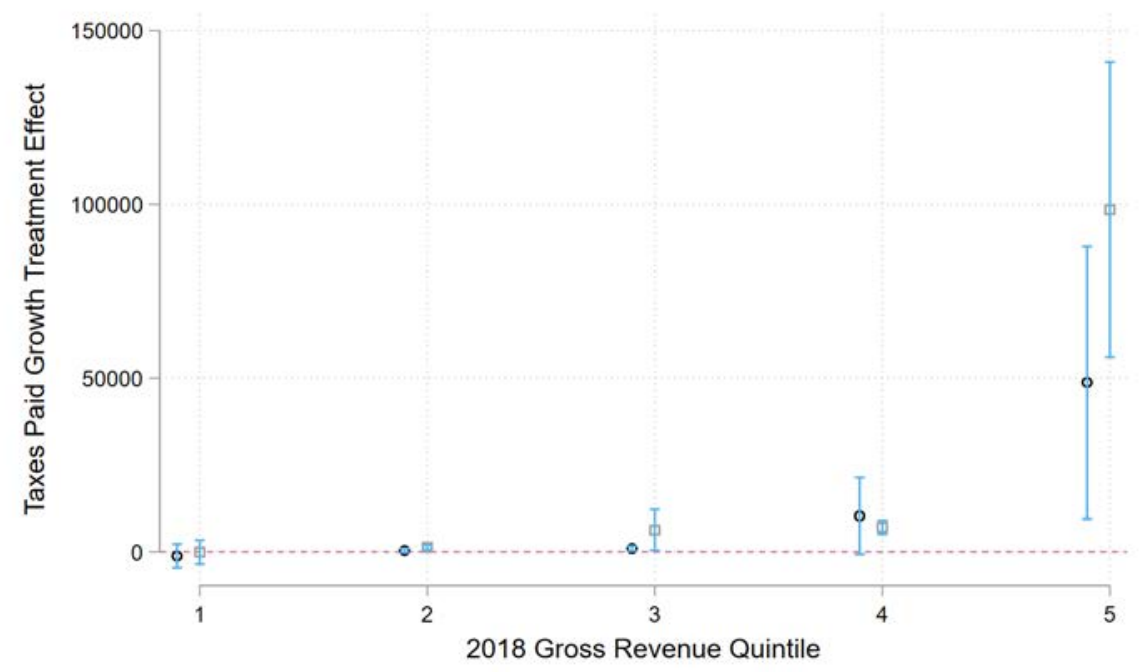

- Prison Time $\square$ Prison Time + Commission

\section{Figure 5: Effect of Public Disclosure Messages by Firm Size}

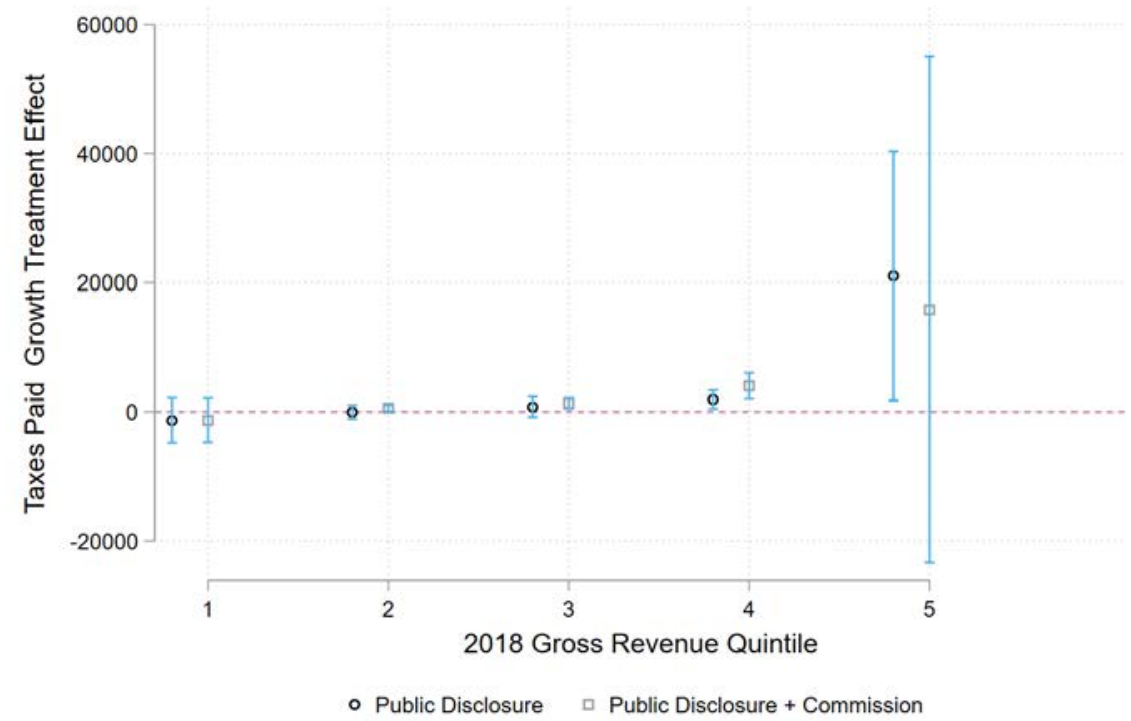

Note: Figures displays difference in growth between the treatment group and control group in a given quintile of firm size along with $90 \%$ confidence intervals. Figure includes 15,965 observations with recorded number of employees. Quintile calculated using the 2018 distribution of the number of employees from the full sample of FY2018 firms. 


\section{A. Appendix}

Table 9: Firm Baseline Outcome Balance

\begin{tabular}{|c|c|c|c|c|c|c|}
\hline & $\begin{array}{c}\text { (1) } \\
\text { FY2018 Taxes Paid }\end{array}$ & $\begin{array}{c}(2) \\
\text { FY2018 Filed Taxes }\end{array}$ & $\begin{array}{c}\text { (3) } \\
\text { FY2018 Gross Revenue }\end{array}$ & $\begin{array}{c}(4) \\
\text { FY2018 Taxable Revenue }\end{array}$ & $\begin{array}{c}\text { (5) } \\
\text { FY2018 Auto Audit }\end{array}$ & $\begin{array}{c}\text { (6) } \\
\text { FY2018 Full Audit }\end{array}$ \\
\hline \multirow[t]{2}{*}{ Commission Framing } & 214.5 & 0.000337 & 127211.4 & 5676.9 & $-0.00612^{*}$ & 0.000530 \\
\hline & $(3828.1)$ & $(0.00726)$ & $(259341.9)$ & $(29167.9)$ & $(0.00354)$ & $(0.000844)$ \\
\hline \multirow[t]{2}{*}{ Public Disclosure } & 324.9 & 0.000203 & 30489.4 & 8701.3 & -0.00459 & -0.000107 \\
\hline & $(3755.9)$ & $(0.00726)$ & $(249369.6)$ & $(28817.4)$ & $(0.00356)$ & $(0.000803)$ \\
\hline \multirow[t]{2}{*}{ Public Disclosure with Commission Framing } & -55.05 & -0.000840 & 259399.9 & -11900.5 & 0.000411 & 0.000751 \\
\hline & $(4726.1)$ & $(0.00727)$ & $(379504.7)$ & $(38984.0)$ & $(0.00363)$ & $(0.000858)$ \\
\hline \multirow[t]{2}{*}{ Prison Time } & 2339.9 & -0.000241 & 168222.9 & 25935.6 & 0.000994 & -0.000105 \\
\hline & (6010.8) & $(0.00727)$ & (367515.5) & $(42529.1)$ & $(0.00363)$ & $(0.000803)$ \\
\hline \multirow[t]{2}{*}{ Prison Time with Commission Framing } & -107.1 & 0.000357 & 13688.6 & 11041.0 & 0.00158 & -0.000214 \\
\hline & $(4472.4)$ & $(0.00726)$ & $(263628.3)$ & $(32687.7)$ & $(0.00364)$ & $(0.000796)$ \\
\hline \multirow[t]{2}{*}{ Constant } & $11824.7^{* * *}$ & $0.548^{* * *}$ & $1122403.6^{* * *}$ & $55424.5^{* *}$ & $0.0658^{* * *}$ & $0.00309^{* * *}$ \\
\hline & $(2932.9)$ & $(0.00514)$ & $(185847.5)$ & $(23379.4)$ & $(0.00256)$ & $(0.000573)$ \\
\hline Subjects & Firms & Firms & Firms & Firms & Firms & Firms \\
\hline Baseline balance & 0.996 & 1.00 & 0.957 & 0.952 & 0.092 & 0.717 \\
\hline Observations & 56310 & 56310 & 30877 & 30877 & 56310 & 56310 \\
\hline
\end{tabular}

Note: Table displays regressions of treatment indicators on FY2018 baselines for outcome measures with robust standard errors in parentheses. Columns (3) and (4) are calculated conditional on filing taxes. ${ }^{*} p<0.10,{ }^{* *} p<0.05,{ }^{* * *} p<0.01$.

Table 10: Self Employed Baseline Outcome Balance

\begin{tabular}{|c|c|c|c|c|c|c|}
\hline & $\begin{array}{c}(1) \\
\text { FY2018 Taxes Paid }\end{array}$ & $\begin{array}{c}\text { (2) } \\
\text { FY2018 Filed Taxes }\end{array}$ & $\begin{array}{c}(3) \\
\text { FY2018 Gross Revenue }\end{array}$ & $\begin{array}{c}(4) \\
\text { FY2018 Taxable Revenue }\end{array}$ & $\begin{array}{c}\text { (5) } \\
\text { FY2018 Auto Audit }\end{array}$ & $\begin{array}{c}\text { (6) } \\
\text { FY2018 Full Audit }\end{array}$ \\
\hline \multirow[t]{2}{*}{ Commission Framing } & 85.17 & 0 & 3541.3 & 307.6 & -0.00669 & -0.000434 \\
\hline & $(392.9)$ & (.) & $(7409.7)$ & $(1578.0)$ & $(0.00565)$ & $(0.000666)$ \\
\hline \multirow[t]{2}{*}{ Public Disclosure } & 87.31 & 0 & -5956.3 & 323.7 & -0.00889 & -0.000426 \\
\hline & (588.6) & (.) & (6623.3) & (2358.6) & $(0.00563)$ & $(0.000669)$ \\
\hline \multirow[t]{2}{*}{ Public Disclosure with Commission Framing } & 42.90 & 0 & -7322.9 & 126.2 & -0.00458 & -0.000631 \\
\hline & $(478.9)$ & (.) & $(7764.5)$ & $(1920.7)$ & $(0.00571)$ & $(0.000636)$ \\
\hline \multirow[t]{2}{*}{ Prison Time } & -268.7 & 0 & -1315.9 & -1095.3 & 0.00202 & 0.000422 \\
\hline & $(366.5)$ & (.) & $(6894.1)$ & $(1472.8)$ & $(0.00580)$ & $(0.000791)$ \\
\hline \multirow[t]{2}{*}{ Prison Time with Commission Framing } & 295.6 & 0 & 8114.3 & 1149.5 & -0.000507 & -0.000385 \\
\hline & $(385.0)$ & (.) & $(9173.0)$ & $(1547.6)$ & $(0.00583)$ & $(0.000682)$ \\
\hline \multirow[t]{2}{*}{ Constant } & $3561.3^{* * *}$ & 1 & $76550.7^{* * *}$ & $16210.6^{* * *}$ & $0.0860^{* * *}$ & $0.00127^{* *}$ \\
\hline & $(279.9)$ & (.) & $(4741.9)$ & $(1124.2)$ & $(0.00408)$ & $(0.000518)$ \\
\hline Subjects & Self-Employed & Self-Employed & Self-Employed & Self-Employed & Self-Employed & Self-Employed \\
\hline Baseline balance & 0.618 & NA & 0.393 & 0.628 & 0.295 & 0.683 \\
\hline Observations & 28179 & 28179 & 28179 & 28179 & 28179 & 28179 \\
\hline
\end{tabular}


Table 11: Firm Characteristics Balance

\begin{tabular}{|c|c|c|c|c|c|c|c|}
\hline & Control & Commission & Prison & $\begin{array}{c}\text { Prison } \\
\text { Public with Commission }\end{array}$ & Public & $\begin{array}{c}\text { Public } \\
\text { Public }+ \text { Commission }\end{array}$ & $\begin{array}{l}\text { F-test for joint } \\
\text { Orthogonality }\end{array}$ \\
\hline Number of Workers & $\begin{array}{l}20.840 \\
(1.632)\end{array}$ & $\begin{array}{l}19.911 \\
(1.420)\end{array}$ & $\begin{array}{l}19.719 \\
(1.584)\end{array}$ & $\begin{array}{l}21.352 \\
(1.726)\end{array}$ & $\begin{array}{l}23.285 \\
(3.714)\end{array}$ & $\begin{array}{l}21.191 \\
(1.646)\end{array}$ & 0.870 \\
\hline Number of observations & 4072 & 3940 & 3886 & 3918 & 3933 & 3999 & \\
\hline Primary Sector & $\begin{array}{c}0.015 \\
(0.001)\end{array}$ & $\begin{array}{c}0.014 \\
(0.001)\end{array}$ & $\begin{array}{c}0.016 \\
(0.001)\end{array}$ & $\begin{array}{c}0.016 \\
(0.001)\end{array}$ & $\begin{array}{c}0.013 \\
(0.001)\end{array}$ & $\begin{array}{c}0.014 \\
(0.001)\end{array}$ & 0.605 \\
\hline Secondary Sector & $\begin{array}{c}0.015 \\
(0.001)\end{array}$ & $\begin{array}{c}0.016 \\
(0.001)\end{array}$ & $\begin{array}{c}0.015 \\
(0.001)\end{array}$ & $\begin{array}{c}0.016 \\
(0.001)\end{array}$ & $\begin{array}{c}0.016 \\
(0.001)\end{array}$ & $\begin{array}{c}0.016 \\
(0.001)\end{array}$ & 0.970 \\
\hline Tertiary Sector & $\begin{array}{c}0.956 \\
(0.002)\end{array}$ & $\begin{array}{c}0.957 \\
(0.002)\end{array}$ & $\begin{array}{c}0.957 \\
(0.002)\end{array}$ & $\begin{array}{c}0.956 \\
(0.002)\end{array}$ & $\begin{array}{c}0.957 \\
(0.002)\end{array}$ & $\begin{array}{c}0.956 \\
(0.002)\end{array}$ & 1.000 \\
\hline Agricultural Services & $\begin{array}{c}0.002 \\
(0.000)\end{array}$ & $\begin{array}{c}0.002 \\
(0.000)\end{array}$ & $\begin{array}{c}0.003 \\
(0.001)\end{array}$ & $\begin{array}{c}0.002 \\
(0.000)\end{array}$ & $\begin{array}{c}0.002 \\
(0.000)\end{array}$ & $\begin{array}{c}0.002 \\
(0.000)\end{array}$ & 0.334 \\
\hline Cereal Cultivation & $\begin{array}{c}0.000 \\
(0.000)\end{array}$ & $\begin{array}{c}0.001 \\
(0.000)\end{array}$ & $\begin{array}{c}0.000 \\
(0.000)\end{array}$ & $\begin{array}{c}0.001 \\
(0.000)\end{array}$ & $\begin{array}{c}0.000 \\
(0.000)\end{array}$ & $\begin{array}{c}0.000 \\
(0.000)\end{array}$ & 0.878 \\
\hline Commerce & $\begin{array}{c}0.694 \\
(0.005)\end{array}$ & $\begin{array}{c}0.696 \\
(0.005)\end{array}$ & $\begin{array}{c}0.695 \\
(0.005)\end{array}$ & $\begin{array}{c}0.696 \\
(0.005)\end{array}$ & $\begin{array}{c}0.696 \\
(0.005)\end{array}$ & $\begin{array}{c}0.697 \\
(0.005)\end{array}$ & 0.998 \\
\hline Communications & $\begin{array}{c}0.004 \\
(0.001)\end{array}$ & $\begin{array}{c}0.004 \\
(0.001)\end{array}$ & $\begin{array}{c}0.004 \\
(0.001)\end{array}$ & $\begin{array}{c}0.004 \\
(0.001)\end{array}$ & $\begin{array}{c}0.003 \\
(0.001)\end{array}$ & $\begin{array}{c}0.003 \\
(0.001)\end{array}$ & 0.466 \\
\hline Construction & $\begin{array}{c}0.009 \\
(0.001)\end{array}$ & $\begin{array}{c}0.009 \\
(0.001)\end{array}$ & $\begin{array}{c}0.009 \\
(0.001)\end{array}$ & $\begin{array}{c}0.010 \\
(0.001)\end{array}$ & $\begin{array}{c}0.009 \\
(0.001)\end{array}$ & $\begin{array}{c}0.009 \\
(0.001)\end{array}$ & 0.970 \\
\hline Educational Services & $\begin{array}{c}0.002 \\
(0.000)\end{array}$ & $\begin{array}{c}0.001 \\
(0.000)\end{array}$ & $\begin{array}{c}0.002 \\
(0.001)\end{array}$ & $\begin{array}{c}0.002 \\
(0.001)\end{array}$ & $\begin{array}{c}0.002 \\
(0.000)\end{array}$ & $\begin{array}{c}0.002 \\
(0.001)\end{array}$ & 0.649 \\
\hline Electricity Gas and Water & $\begin{array}{c}0.002 \\
(0.000)\end{array}$ & $\begin{array}{c}0.002 \\
(0.001)\end{array}$ & $\begin{array}{c}0.002 \\
(0.000)\end{array}$ & $\begin{array}{c}0.003 \\
(0.001)\end{array}$ & $\begin{array}{c}0.002 \\
(0.000)\end{array}$ & $\begin{array}{c}0.003 \\
(0.001)\end{array}$ & 0.630 \\
\hline Financial & $\begin{array}{c}0.008 \\
(0.001)\end{array}$ & $\begin{array}{c}0.006 \\
(0.001)\end{array}$ & $\begin{array}{c}0.006 \\
(0.001)\end{array}$ & $\begin{array}{c}0.006 \\
(0.001)\end{array}$ & $\begin{array}{c}0.007 \\
(0.001)\end{array}$ & $\begin{array}{c}0.006 \\
(0.001)\end{array}$ & 0.561 \\
\hline Health services & $\begin{array}{c}0.005 \\
(0.001)\end{array}$ & $\begin{array}{c}0.004 \\
(0.001)\end{array}$ & $\begin{array}{c}0.004 \\
(0.001)\end{array}$ & $\begin{array}{c}0.004 \\
(0.001)\end{array}$ & $\begin{array}{c}0.004 \\
(0.001)\end{array}$ & $\begin{array}{c}0.005 \\
(0.001)\end{array}$ & 0.387 \\
\hline Hotels Bars and Restaurants & $\begin{array}{c}0.006 \\
(0.001)\end{array}$ & $\begin{array}{c}0.006 \\
(0.001)\end{array}$ & $\begin{array}{c}0.006 \\
(0.001)\end{array}$ & $\begin{array}{c}0.006 \\
(0.001)\end{array}$ & $\begin{array}{c}0.005 \\
(0.001)\end{array}$ & $\begin{array}{c}0.005 \\
(0.001)\end{array}$ & 0.905 \\
\hline Livestock Forestry and Fishing & $\begin{array}{c}0.002 \\
(0.000)\end{array}$ & $\begin{array}{c}0.002 \\
(0.000)\end{array}$ & $\begin{array}{c}0.002 \\
(0.000)\end{array}$ & $\begin{array}{c}0.002 \\
(0.000)\end{array}$ & $\begin{array}{c}0.002 \\
(0.000)\end{array}$ & $\begin{array}{c}0.003 \\
(0.001)\end{array}$ & 0.251 \\
\hline Manufacturing & $\begin{array}{c}0.007 \\
(0.001)\end{array}$ & $\begin{array}{c}0.007 \\
(0.001)\end{array}$ & $\begin{array}{c}0.008 \\
(0.001)\end{array}$ & $\begin{array}{c}0.008 \\
(0.001)\end{array}$ & $\begin{array}{c}0.007 \\
(0.001)\end{array}$ & $\begin{array}{c}0.008 \\
(0.001)\end{array}$ & 0.999 \\
\hline Mining and Quarry Exploitation & $\begin{array}{c}0.001 \\
(0.000)\end{array}$ & $\begin{array}{c}0.000 \\
(0.000)\end{array}$ & $\begin{array}{c}0.001 \\
(0.000)\end{array}$ & $\begin{array}{c}0.001 \\
(0.000)\end{array}$ & $\begin{array}{c}0.001 \\
(0.000)\end{array}$ & $\begin{array}{c}0.001 \\
(0.000)\end{array}$ & 0.787 \\
\hline Other services & $\begin{array}{c}0.011 \\
(0.001)\end{array}$ & $\begin{array}{c}0.011 \\
(0.001)\end{array}$ & $\begin{array}{c}0.011 \\
(0.001)\end{array}$ & $\begin{array}{c}0.010 \\
(0.001)\end{array}$ & $\begin{array}{c}0.010 \\
(0.001)\end{array}$ & $\begin{array}{c}0.010 \\
(0.001)\end{array}$ & 0.950 \\
\hline Public Administration & $\begin{array}{c}0.001 \\
(0.000)\end{array}$ & $\begin{array}{c}0.001 \\
(0.000)\end{array}$ & $\begin{array}{c}0.001 \\
(0.000)\end{array}$ & $\begin{array}{c}0.000 \\
(0.000)\end{array}$ & $\begin{array}{c}0.001 \\
(0.000)\end{array}$ & $\begin{array}{c}0.001 \\
(0.000)\end{array}$ & 0.838 \\
\hline Rental Housing & $\begin{array}{c}0.237 \\
(0.004)\end{array}$ & $\begin{array}{c}0.239 \\
(0.004)\end{array}$ & $\begin{array}{c}0.239 \\
(0.004)\end{array}$ & $\begin{array}{c}0.238 \\
(0.004)\end{array}$ & $\begin{array}{c}0.239 \\
(0.004)\end{array}$ & $\begin{array}{c}0.237 \\
(0.004)\end{array}$ & 0.997 \\
\hline Traditional Crops & $\begin{array}{c}0.002 \\
(0.000)\end{array}$ & $\begin{array}{c}0.002 \\
(0.000)\end{array}$ & $\begin{array}{c}0.003 \\
(0.001)\end{array}$ & $\begin{array}{c}0.003 \\
(0.001)\end{array}$ & $\begin{array}{c}0.002 \\
(0.000)\end{array}$ & $\begin{array}{c}0.002 \\
(0.001)\end{array}$ & 0.351 \\
\hline Transportation and Storage & $\begin{array}{c}0.006 \\
(0.001)\end{array}$ & $\begin{array}{c}0.007 \\
(0.001)\end{array}$ & $\begin{array}{c}0.006 \\
(0.001)\end{array}$ & $\begin{array}{c}0.005 \\
(0.001)\end{array}$ & $\begin{array}{c}0.007 \\
(0.001)\end{array}$ & $\begin{array}{c}0.006 \\
(0.001)\end{array}$ & 0.757 \\
\hline Missing Sector & $\begin{array}{c}0.000 \\
(0.000)\end{array}$ & $\begin{array}{c}0.000 \\
(0.000)\end{array}$ & $\begin{array}{c}0.000 \\
(0.000)\end{array}$ & $\begin{array}{c}0.000 \\
(0.000)\end{array}$ & $\begin{array}{c}0.000 \\
(0.000)\end{array}$ & $\begin{array}{c}0.001 \\
(0.000)\end{array}$ & 0.821 \\
\hline N & 9386 & 9393 & 9388 & 9373 & 9381 & 9389 & \\
\hline
\end{tabular}

Note: Table includes the mean of each variable by treatment group. Standard errors are presented below the mean in parentheses. Right column displays the p-value from an F-test evaluating whether all equal in all groups. 


\section{Table 12: Self-Employed Characteristics Balance}

\begin{tabular}{|c|c|c|c|c|c|c|c|}
\hline & Control & Commission & Prison & $\begin{array}{c}\text { Prison } \\
\text { Public with Commission }\end{array}$ & Public & $\begin{array}{c}\text { Public } \\
\text { Public }+ \text { Commission }\end{array}$ & $\begin{array}{l}\text { F-test for joint } \\
\text { Orthogonality }\end{array}$ \\
\hline Female & $\begin{array}{c}0.321 \\
(0.007)\end{array}$ & $\begin{array}{c}0.319 \\
(0.007)\end{array}$ & $\begin{array}{c}0.321 \\
(0.007)\end{array}$ & $\begin{array}{c}0.323 \\
(0.007)\end{array}$ & $\begin{array}{c}0.318 \\
(0.007)\end{array}$ & $\begin{array}{c}0.326 \\
(0.007)\end{array}$ & 0.972 \\
\hline Married & $\begin{array}{c}0.223 \\
(0.006)\end{array}$ & $\begin{array}{c}0.220 \\
(0.006)\end{array}$ & $\begin{array}{c}0.216 \\
(0.006)\end{array}$ & $\begin{array}{c}0.218 \\
(0.006)\end{array}$ & $\begin{array}{c}0.225 \\
(0.006)\end{array}$ & $\begin{array}{c}0.225 \\
(0.006)\end{array}$ & 0.878 \\
\hline White & $\begin{array}{c}0.178 \\
(0.006)\end{array}$ & $\begin{array}{c}0.179 \\
(0.006)\end{array}$ & $\begin{array}{c}0.183 \\
(0.006)\end{array}$ & $\begin{array}{c}0.176 \\
(0.006)\end{array}$ & $\begin{array}{c}0.177 \\
(0.006)\end{array}$ & $\begin{array}{c}0.178 \\
(0.006)\end{array}$ & 0.964 \\
\hline Gross income declared in 2018 & $\begin{array}{l}76550.688 \\
(4741.893)\end{array}$ & $\begin{array}{l}80091.948 \\
(5693.636)\end{array}$ & $\begin{array}{l}70594.352 \\
(4624.180)\end{array}$ & $\begin{array}{l}69227.798 \\
(6148.368)\end{array}$ & $\begin{array}{l}75234.761 \\
(5004.317)\end{array}$ & $\begin{array}{l}84664.985 \\
(7852.265)\end{array}$ & 0.415 \\
\hline Taxes paid in 2018 & $\begin{array}{l}3561.301 \\
(279.932)\end{array}$ & $\begin{array}{l}3646.474 \\
(275.626)\end{array}$ & $\begin{array}{l}3648.613 \\
(517.788)\end{array}$ & $\begin{array}{l}3604.199 \\
(388.532)\end{array}$ & $\begin{array}{l}3292.565 \\
(236.567)\end{array}$ & $\begin{array}{l}3856.870 \\
(264.365)\end{array}$ & 0.924 \\
\hline Taxable income declared in 2018 & $\begin{array}{l}16210.615 \\
(1124.229)\end{array}$ & $\begin{array}{l}16518.262 \\
(1107.350)\end{array}$ & $\begin{array}{l}16534.349 \\
(2073.412)\end{array}$ & $\begin{array}{l}16336.855 \\
(1557.243)\end{array}$ & $\begin{array}{l}15115.347 \\
(951.373)\end{array}$ & $\begin{array}{l}17360.143 \\
(1063.603)\end{array}$ & 0.927 \\
\hline Paid any taxes in 2018 & $\begin{array}{c}0.997 \\
(0.001)\end{array}$ & $\begin{array}{c}0.997 \\
(0.001)\end{array}$ & $\begin{array}{c}0.998 \\
(0.001)\end{array}$ & $\begin{array}{c}0.996 \\
(0.001)\end{array}$ & $\begin{array}{c}0.997 \\
(0.001)\end{array}$ & $\begin{array}{c}0.997 \\
(0.001)\end{array}$ & 0.471 \\
\hline $\mathrm{N}$ & 4723 & 4781 & 4736 & 4694 & 4728 & 4517 & \\
\hline
\end{tabular}

Note: Table includes the mean of each variable by treatment group. Standard errors are presented below the mean in parentheses. Right column displays the $\mathrm{p}$-value from an F-test evaluating whether all equal in all groups. 


\section{Table 13: Firm Representativeness}

\begin{tabular}{|c|c|c|c|c|c|c|c|c|}
\hline & $\begin{array}{c}(1) \\
\text { Employees }\end{array}$ & $\begin{array}{c}(2) \\
\text { Filed Taxes }\end{array}$ & $\begin{array}{c}\text { (3) } \\
\text { Gross Revenue }\end{array}$ & $\begin{array}{c}(4) \\
\text { Taxable Revenue }\end{array}$ & $\begin{array}{c}(5) \\
\text { Declared Exempt }\end{array}$ & $\begin{array}{c}(6) \\
\text { Taxes Paid }\end{array}$ & $\begin{array}{c}\text { (7) } \\
\text { Auto Audit }\end{array}$ & $\begin{array}{l}\text { (8) } \\
\text { Full Audit }\end{array}$ \\
\hline Included in Experiment & $\begin{array}{l}2.207^{*} \\
(1.158)\end{array}$ & $\begin{array}{l}-0.00442^{*} \\
(0.00257)\end{array}$ & $\begin{array}{c}650228.9^{* * *} \\
(103815.0)\end{array}$ & $\begin{array}{c}44635.4^{* * *} \\
(12085.6)\end{array}$ & $\begin{array}{c}-0.117^{* * * *} \\
(0.00340)\end{array}$ & $\begin{array}{c}7448.7^{* * *} \\
(1660.4)\end{array}$ & $\begin{array}{c}0.0584^{* * *} \\
(0.00106)\end{array}$ & $\begin{array}{c}0.00312^{* * * *} \\
(0.000241)\end{array}$ \\
\hline Constant & $\begin{array}{c}18.72^{* * *} \\
(0.790)\end{array}$ & $\begin{array}{l}0.553^{* * *} \\
(0.00148)\end{array}$ & $\begin{array}{c}571907.0 * * * \\
(36778.8)\end{array}$ & $\begin{array}{c}17371.4^{* * *} \\
(6172.6)\end{array}$ & $\begin{array}{l}0.675^{* * *} \\
(0.00188)\end{array}$ & $\begin{array}{c}4828.7^{* * *} \\
(857.4)\end{array}$ & $\begin{array}{c}0.00613^{* * *} \\
(0.000233)\end{array}$ & $\begin{array}{r}0.000116^{* * * *} \\
(0.0000321)\end{array}$ \\
\hline Observations & 69067 & 168497 & 92889 & 92889 & 92889 & 168497 & 168497 & 168497 \\
\hline
\end{tabular}

Note: Table displays regression coefficeints from regressions of FY2018 baseline outcomes on an indicator for whether the firm was sent a message. Robus standard errors shown in parentheses. ${ }^{*} p<0.10,{ }^{* *} p<0.05,{ }^{* * *} p<0.01$.

\section{Table 14: Self-Employed Representativeness}

\begin{tabular}{|c|c|c|c|c|c|c|c|}
\hline & $\begin{array}{c}(1) \\
\text { Filed Taxes }\end{array}$ & $\begin{array}{c}(2) \\
\text { Gross Revenue }\end{array}$ & $\begin{array}{c}\text { (3) } \\
\text { Taxable Revenue }\end{array}$ & $\begin{array}{c}(4) \\
\text { Declared Exempt }\end{array}$ & $\begin{array}{c}(5) \\
\text { Taxes Paid }\end{array}$ & $\begin{array}{c}\text { (6) } \\
\text { Auto Audit }\end{array}$ & $\begin{array}{l}\text { (7) } \\
\text { Full Audit }\end{array}$ \\
\hline \multirow[t]{2}{*}{ Included in Experiment } & 0 & -1966.7 & $5674.8^{* * *}$ & $-0.132 * * *$ & $1274.8^{* * *}$ & $0.00957^{* * *}$ & 0.000206 \\
\hline & (.) & $(4131.4)$ & $(684.5)$ & $(0.00438)$ & (170.3) & $(0.00264)$ & $(0.000298)$ \\
\hline \multirow[t]{2}{*}{ Constant } & 1 & $77977.2^{* * *}$ & $10663.9^{* * *}$ & $0.775^{* * *}$ & $2325.0^{* * *}$ & $0.0733^{* * *}$ & $0.000823^{* * *}$ \\
\hline & (.) & $(3400.2)$ & (393.1) & $(0.00332)$ & $(97.41)$ & $(0.00207)$ & $(0.000228)$ \\
\hline Observations & 43972 & 43972 & 43972 & 43972 & 43972 & 43972 & 43972 \\
\hline
\end{tabular}




\section{Table 15: Summary Statistics by Quintile (Full sample)}

\begin{tabular}{|c|c|c|c|c|c|c|c|c|c|c|}
\hline & & $1^{\text {st }}$ Quintile & & $2^{n d}$ Quintile & & $3^{\text {rd }}$ Quintile & & $4^{\text {th }}$ Quintile & & $5^{t h}$ Quintile \\
\hline \multirow[t]{2}{*}{ Number of Workers } & 13952 & 1.000 & 17074 & 2.425 & 13354 & 4.834 & 11591 & 9.313 & 13096 & 85.378 \\
\hline & & $(0.000)$ & & $(0.004)$ & & $(0.007)$ & & $(0.018)$ & & $(3.060)$ \\
\hline \multirow[t]{2}{*}{ Gross income declared in 2018} & 8809 & 78380 & 11929 & 100648 & 10172 & 214766 & 9472 & 441703 & 11555 & 5423977 \\
\hline & & (7689) & & $(3362)$ & & (21422) & & $(27517)$ & & (320710) \\
\hline \multirow[t]{2}{*}{ Taxable income declared in 2018} & 8809 & -1822 & 11929 & 141 & 10172 & 2421 & 9472 & 6119 & 11555 & 258011 \\
\hline & & (683) & & $(566)$ & & (2382) & & (3463) & & (42966) \\
\hline \multirow[t]{2}{*}{ Declared Exempt Level of Taxes in 2018} & 8809 & 0.612 & 11929 & 0.540 & 10172 & 0.479 & 9472 & 0.423 & 11555 & 0.348 \\
\hline & & $(0.005)$ & & $(0.005)$ & & $(0.005)$ & & $(0.005)$ & & $(0.004)$ \\
\hline \multirow[t]{2}{*}{ Taxes paid in 2018} & 13952 & 807.121 & 17074 & 1222.183 & 13354 & 2660.561 & 11591 & 4881.418 & 13096 & 81945.512 \\
\hline & & $(51.277)$ & & $(60.340)$ & & $(396.411)$ & & $(359.276)$ & & (9516.165) \\
\hline \multirow[t]{2}{*}{ Sector Unclassified } & 13952 & 0.226 & 17074 & 0.205 & 13354 & 0.187 & 11591 & 0.165 & 13096 & 0.156 \\
\hline & & $(0.004)$ & & $(0.003)$ & & $(0.003)$ & & $(0.003)$ & & $(0.003)$ \\
\hline \multirow[t]{2}{*}{ Primary Sector } & 13952 & 0.143 & 17074 & 0.117 & 13354 & 0.097 & 11591 & 0.089 & 13096 & 0.091 \\
\hline & & $(0.003)$ & & $(0.002)$ & & $(0.003)$ & & $(0.003)$ & & $(0.003)$ \\
\hline \multirow[t]{2}{*}{ Secondary Sector } & 13952 & 0.107 & 17074 & 0.109 & 13354 & 0.126 & 11591 & 0.142 & 13096 & 0.199 \\
\hline & & $(0.003)$ & & $(0.002)$ & & $(0.003)$ & & $(0.003)$ & & $(0.003)$ \\
\hline \multirow[t]{2}{*}{ Tertiary Sector } & 13952 & 0.524 & 17074 & 0.570 & 13354 & 0.590 & 11591 & 0.604 & 13096 & 0.554 \\
\hline & & $(0.004)$ & & $(0.004)$ & & $(0.004)$ & & $(0.005)$ & & $(0.004)$ \\
\hline
\end{tabular}

Note: Table displays the average characteristics for firms in different quintiles of firm size. The number of observations appears to the right of the mean and standard errors appear below the mean in parentheses. This table includes all of the firms in our sample of data with a recorded number of firms. Sample Sizes differ across quintiles because of ties.

\section{Table 16: Summary Statistics by Quintile (Experimental Sample)}

\begin{tabular}{|c|c|c|c|c|c|c|c|c|c|c|}
\hline & & $1^{\text {st }}$ Quintile & & $2^{\text {nd }}$ Quintile & & $3^{r d}$ Quintile & & $4^{t h}$ Quintile & & $5^{\text {th }}$ Quintile \\
\hline \multirow[t]{2}{*}{ Number of Workers } & 4409 & 1.000 & 5686 & 2.434 & 4632 & 4.843 & 4212 & 9.350 & 5189 & 81.865 \\
\hline & & $(0.000)$ & & $(0.007)$ & & $(0.012)$ & & $(0.030)$ & & (3.817) \\
\hline \multirow[t]{2}{*}{ Gross income declared in 2018} & 2810 & 86636 & 4042 & 126242 & 3638 & 294450 & 3569 & 626973 & 4805 & 6832491 \\
\hline & & $(5711)$ & & $(5596)$ & & (53758) & & (62639) & & (613964) \\
\hline \multirow[t]{2}{*}{ Taxable income declared in 2018} & 2810 & -1012 & 4042 & 2374 & 3638 & 997 & 3569 & 21002 & 4805 & 384253 \\
\hline & & $(1285)$ & & $(1013)$ & & $(4053)$ & & $(3886)$ & & $(66345)$ \\
\hline \multirow[t]{2}{*}{ Declared Exempt Level of Taxes in 2018} & 2810 & 0.573 & 4042 & 0.498 & 3638 & 0.435 & 3569 & 0.341 & 4805 & 0.236 \\
\hline & & $(0.009)$ & & $(0.008)$ & & $(0.008)$ & & $(0.008)$ & & $(0.006)$ \\
\hline \multirow[t]{2}{*}{ Taxes paid in 2018} & 4409 & 1108 & 5686 & 1693 & 4632 & 3157 & 4212 & 7281 & 5189 & 118824 \\
\hline & & (125) & & (149) & & (318) & & (868) & & (15330) \\
\hline \multirow[t]{2}{*}{ Sector Unclassified } & 4409 & 0.007 & 5686 & 0.011 & 4632 & 0.011 & 4212 & 0.023 & 5189 & 0.071 \\
\hline & & $(0.001)$ & & $(0.001)$ & & $(0.002)$ & & $(0.002)$ & & $(0.004)$ \\
\hline \multirow[t]{2}{*}{ Primary Sector } & 4409 & 0.015 & 5686 & 0.017 & 4632 & 0.021 & 4212 & 0.026 & 5189 & 0.057 \\
\hline & & $(0.002)$ & & $(0.002)$ & & $(0.002)$ & & $(0.002)$ & & $(0.003)$ \\
\hline \multirow[t]{2}{*}{ Secondary Sector } & 4409 & 0.010 & 5686 & 0.009 & 4632 & 0.016 & 4212 & 0.031 & 5189 & 0.090 \\
\hline & & $(0.002)$ & & $(0.001)$ & & $(0.002)$ & & $(0.003)$ & & $(0.004)$ \\
\hline \multirow[t]{2}{*}{ Tertiary Sector } & 4409 & 0.968 & 5686 & 0.963 & 4632 & 0.953 & 4212 & 0.920 & 5189 & 0.782 \\
\hline & & $(0.003)$ & & $(0.003)$ & & $(0.003)$ & & $(0.004)$ & & $(0.006)$ \\
\hline
\end{tabular}

Note:Table displays the average characteristics for firms in different quintiles of firm size. The number of observations appears to the right of the mean and standard errors appear below the mean in parentheses. This table includes all of the firms in our sample of data with a recorded number of firms who were sent messages. Sample Sizes differ across quintiles because the quintile is calculated using the full sample. 


\section{References}

Allingham, Michael G and Agnar Sandmo, "Income tax evasion: A theoretical analysis," Journal of public economics, 1972, 1 (3-4), 323-338.

Alm, James, Gary H McClelland, and William D Schulze, "Why do people pay taxes?," Journal of public Economics, 1992, 48 (1), 21-38.

Antinyan, Armenak and Zareh Asatryan, "Nudging for tax compliance: A meta-analysis," ZEW-Centre for European Economic Research Discussion Paper, 2019, (19-055).

Ariel, Barak, "Deterrence and moral persuasion effects on corporate tax compliance: findings from a randomized controlled trial," Criminology, 2012, 50 (1), 27-69.

Becker, Gary S, "Crime and punishment: An economic approach," in "The economic dimensions of crime," Springer, 1968, pp. 13-68.

Bénabou, Roland and Jean Tirole, "Incentives and prosocial behavior," American Economic Review, 2006, 96 (5), 1652-1678.

Bérgolo, Marcelo L, Rodrigo Ceni, Guillermo Cruces, Matias Giaccobasso, and Ricardo Perez-Truglia, "Tax audits as scarecrows: Evidence from a large-scale field experiment,” Technical Report, National Bureau of Economic Research 2017.

Besley, Timothy and Maitreesh Ghatak, "Property rights and economic development," in "Handbook of development economics," Vol. 5, Elsevier, 2010, pp. 4525-4595.

— and Torsten Persson, "Why do developing countries tax so little?," Journal of Economic Perspectives, 2014, 28 (4), 99-120.

Blumenthal, Marsha, Charles Christian, Joel Slemrod, and Matthew G Smith, "Do normative appeals affect tax compliance? Evidence from a controlled experiment in Minnesota," National Tax Journal, 2001, pp. 125-138. 
Bø, Erlend E, Joel Slemrod, and Thor O Thoresen, "Taxes on the internet: Deterrence effects of public disclosure," American Economic Journal: Economic Policy, 2015, 7 (1), 36-62.

Brockmeyer, Anne, Spencer Smith, Marco Hernandez, and Stewart Kettle, "Casting a wider tax net: Experimental evidence from Costa Rica," American Economic Journal: Economic Policy, 2019, 11 (3), 55-87.

Bursztyn, Leonardo and Robert Jensen, "Social image and economic behavior in the field: Identifying, understanding, and shaping social pressure," Annual Review of Economics, 2017, 9, 131-153.

Butera, Luigi, Robert Metcalfe, William Morrison, and Dmitry Taubinsky, "The deadweight loss of social recognition," Technical Report, National Bureau of Economic Research 2019.

Carpio, Lucia Del, "Are the neighbors cheating? Evidence from a social norm experiment on property taxes in Peru," Princeton, NJ, Princeton University Working Paper, 2013.

Charness, Gary and Matthias Sutter, "Groups make better self-interested decisions," Journal of Economic Perspectives, 2012, 26 (3), 157-76.

Denant-Boemont, Laurent, Enrico Diecidue, and Olivier L'haridon, "Patience and time consistency in collective decisions," Experimental economics, 2017, 20 (1), 181-208.

DeScioli, Peter, John Christner, and Robert Kurzban, "The omission strategy," Psychological Science, 2011, 22 (4), 442-446.

Dirección General de Impuestos Internos, “Memorias 2016-2020,” 2020.

Doerrenberg, Philipp and Jan Schmitz, "Tax compliance and information provision-A field experiment with small firms," ZEW-Centre for European Economic Research Discussion Paper, 2015, (15-028). 
Du, Shuili and Edward T Vieira, "Striving for legitimacy through corporate social responsibility: Insights from oil companies,” Journal of Business Ethics, 2012, 110 (4), 413-427.

Dwenger, Nadja and Lukas Treber, "Shaming for tax enforcement: Evidence from a new policy," 2018.

Gobierno de la República Dominicana: Equipo Interinstitucional, "Estimación del Incumplimiento Tributario en la República Dominicana,” 2018.

Hallsworth, Michael, “The use of field experiments to increase tax compliance," Oxford Review of Economic Policy, 2014, 30 (4), 658-679.

_ , John A List, Robert D Metcalfe, and Ivo Vlaev, “The making of homo honoratus: From omission to commission,” Technical Report, National Bureau of Economic Research 2015.

${ }_{-}, \ldots, \ldots$, and _ , "The behavioralist as tax collector: Using natural field experiments to enhance tax compliance," Journal of Public Economics, 2017, 148, 14-31.

Hanlon, Michelle and Joel Slemrod, "What does tax aggressiveness signal? Evidence from stock price reactions to news about tax shelter involvement," Journal of Public Economics, 2009, 93 (1-2), 126-141.

Harju, Jarkko, Tuomas Kosonen, and Olli Ropponen, "Do honest hairdressers get a haircut?," in "Proceedings. Annual Conference on Taxation and Minutes of the Annual Meeting of the National Tax Association,” Vol. 107 JSTOR 2014, pp. 1-32.

Harrison, Glenn W and John A List, “Field experiments,” Journal of Economic Literature, 2004, 42 (4), 1009-1055.

Hasegawa, Makoto, Jeffrey L Hoopes, Ryo Ishida, and Joel B Slemrod, “The effect of public disclosure on reported taxable income: Evidence from individuals and corporations in Japan," Available at SSRN 1653948, 2012. 
Hasseldine, John, Peggy Hite, Simon James, and Marika Toumi, "Persuasive communications: Tax compliance enforcement strategies for sole proprietors," Contemporary Accounting Research, 2007, 24 (1), 171-194.

Hedblom, Daniel, Brent R Hickman, and John A List, "Toward an Understanding of Corporate Social Responsibility: Theory and Field Experimental Evidence," Technical Report, National Bureau of Economic Research 2019.

Hoopes, Jeffrey L, Leslie Robinson, and Joel Slemrod, "Public tax-return disclosure," Journal of Accounting and Economics, 2018, 66 (1), 142-162.

Kettle, Stewart, Marco Hernandez, Simon Ruda, and Michael A Sanderson, "Behavioral Interventions in Tax Compliance: Evidence from Guatemala," World Bank Policy Research Working Paper, 2016, (7690).

Kleven, Henrik Jacobsen, Claus Thustrup Kreiner, and Emmanuel Saez, "Why can modern governments tax so much? An agency model of firms as fiscal intermediaries," Economica, 2016, 83 (330), 219-246.

_ , Martin B Knudsen, Claus Thustrup Kreiner, Søren Pedersen, and Emmanuel Saez, "Unwilling or unable to cheat? Evidence from a tax audit experiment in Denmark," Econometrica, 2011, 79 (3), 651-692.

Kumler, Todd, Eric Verhoogen, and Judith A Frías, "Enlisting employees in improving payroll-tax compliance: Evidence from Mexico,” Technical Report, National Bureau of Economic Research 2013.

Latinobarómetro Corporation, “Latinobarómetro Databank,” 2016.

Lee, David S and Justin McCrary, "The Deterrence Effect of Prison: Dynamic Theory and Evidence," in "Regression Discontinuity Designs (Advances in Econometrics)," Vol. 38, Emerald Publishing Limited, 2017. 
List, John A, "Non est Disputandum de Generalizability? A Glimpse into The External Validity Trial,” Technical Report, National Bureau of Economic Research 2020.

_ and Fatemeh Momeni, "When corporate social responsibility backfires: Theory and evidence from a natural field experiment,” Technical Report, National Bureau of Economic Research 2017.

Luttmer, Erzo FP and Monica Singhal, “Tax morale,” Journal of Economic Perspectives, 2014, 28 (4), 149-68.

Mascagni, Giulia, Christopher Nell, and Nara Monkam, "One size does not fit all: a field experiment on the drivers of tax compliance and delivery methods in Rwanda," 2017.

McDonnell, Mary-Hunter and Brayden King, "Keeping up appearances: Reputational threat and impression management after social movement boycotts," Administrative Science Quarterly, 2013, 58 (3), 387-419.

Neve, Jan-Emmanuel De, Clement Imbert, Johannes Spinnewijn, Teodora Tsankova, and Maarten Luts, "How to improve tax compliance? Evidence from population-wide experiments in Belgium," Evidence from Population-Wide Experiments in Belgium (May 05, 2019). Saïd Business School WP, 2019, 7.

Perez-Truglia, Ricardo and Ugo Troiano, "Shaming tax delinquents," Journal of Public Economics, 2018, 167, 120-137.

Pomeranz, Dina, "No taxation without information: Deterrence and self-enforcement in the value added tax," American Economic Review, 2015, 105 (8), 2539-69.

Servaes, Henri and Ane Tamayo, "The impact of corporate social responsibility on firm value: The role of customer awareness," Management Science, 2013, 59 (5), 1045-1061.

Slemrod, Joel, “Tax compliance and enforcement: New research and its policy implications," 2016. 
_ , “Tax compliance and enforcement," Journal of Economic Literature, 2019, 57 (4), 904-54.

_ , Marsha Blumenthal, and Charles Christian, "Taxpayer response to an increased probability of audit: evidence from a controlled experiment in Minnesota," Journal of Public Economics, 2001, 79 (3), 455-483.

Smith, Adam, "An inquiry into the wealth of nations," Strahan and Cadell, London, 1776, pp. 1-11.

Spranca, Mark, Elisa Minsk, and Jonathan Baron, "Omission and commission in judgment and choice," Journal of Experimental Social Psychology, 1991, 27 (1), 76-105.

Torgler, Benno, “Tax morale in Asian countries,” Journal of Asian Economics, 2004, 15 (2), 237-266. 